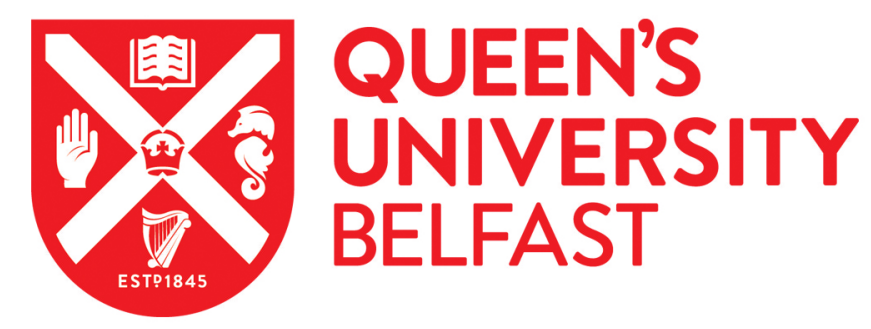

\title{
Transport Infrastructure, Growth and Persistence: The Rise and Demise of the Sui Canal
}

Flückiger, M., \& Ludwig, M. (2019). Transport Infrastructure, Growth and Persistence: The Rise and Demise of the Sui Canal. Canadian Journal of Economics, 52(2), 624-666. https://doi.org/10.1111/caje.12378

Published in:

Canadian Journal of Economics

Document Version:

Peer reviewed version

Queen's University Belfast - Research Portal:

Link to publication record in Queen's University Belfast Research Portal

Publisher rights

( 2019 Canadian Economics Association. This work is made available online in accordance with the publisher's policies. Please refer to any applicable terms of use of the publisher.

\section{General rights}

Copyright for the publications made accessible via the Queen's University Belfast Research Portal is retained by the author(s) and / or other copyright owners and it is a condition of accessing these publications that users recognise and abide by the legal requirements associated with these rights.

Take down policy

The Research Portal is Queen's institutional repository that provides access to Queen's research output. Every effort has been made to ensure that content in the Research Portal does not infringe any person's rights, or applicable UK laws. If you discover content in the Research Portal that you believe breaches copyright or violates any law, please contact openaccess@qub.ac.uk. 


\title{
Transport Infrastructure, Growth and Persistence: The Rise and Demise of the Sui Canal
}

\author{
Matthias Flückiger* $\quad$ Markus Ludwig ${ }^{\dagger}$
}

May 15, 2018

\begin{abstract}
This paper investigates the effect of transport infrastructure on the spatial distribution of population over two millennia. Focusing on the Sui Canal, one of history's greatest infrastructure projects, we show that its completion in the 7th century CE led to a strong increase in population concentration along the newly established transport artery. We exploit the fact that large parts of the canal fell into disrepair after the 12 th century to analyze the persistence of this effect. We find that in 2010, more than 800 years after the Sui Canal fell into disuse, regions once directly connected to the canal are still more populous than areas that never had access. However, this population concentration is not mirrored in economic development. GDP per capita is lower in areas that lay along the course of the canal. One potential explanation for this finding is a change in the value of locational fundamentals as well as a shift in investments to the benefit of coastal regions since the initiation of the Open Door policy in 1978.
\end{abstract}

JEL CLASSIFICATION: O1, O18, R1, R4

Keywords: Transportation, Population Concentration, Growth, Persistence, Sui Canal, China

${ }^{*}$ Queen's University Belfast. Email: matthias.flueckiger@qub.ac.uk

${ }^{\dagger}$ University of Bayreuth. Email: markus.ludwig@uni-bayreuth.de 


\section{Introduction}

There is an active discussion about the main factors that determine the spatial distribution of population and economic activity. While geography's influence is well documented, there is increasing evidence indicating that (historical) man-made advantages permanently influence the spatial pattern of development. For example, transport infrastructure projects, such as the construction of railway lines, have been shown to cause population growth and economic development along the newly established transport networks (Hornung, 2015, Donaldson and Hornbeck, 2016, Donaldson, Forthcoming). These effects can influence the spatial distribution of population and economic activity even long after the transport network has ceased to be operational (Jedwab and Moradi, 2016, Jedwab et al., 2017).

Common to the studies mentioned above is their focus on recent time periods, not reaching back more than 200 years. It is unclear whether (pre-industrial) infrastructure projects that date back further have similar effects on the spatial structure of the economy. Over the long run, the probability increases that the value of locational fundamentals changes. If these changes are large enough to overcome existing local increasing returns, this will lead to a new spatial equilibrium. Depending on the relative speed of adjustment of population and investment, this could lead to lock-in effects, where population is (temporarily) trapped in locationally disadvantaged areas. This could result in a reduction in income. Addressing these questions is aim of this paper. In this study, we analyze the effects of transport infrastructure on local population concentration over a period of more than two millennia. Specifically, we investigate how the construction of the Sui Canal at the beginning of 7th century CE influenced the spatial distribution of population over the long run. The canal - more than 2,500 kilometers long — provided a direct link between North and South China (Needham et al., 1971, p.310). Our empirical analysis focuses on the North China Plain and the Lower Yangtze region, i.e., the areas that lay within the reach of the Sui Canal (see Figure 1). We divide this area, which today contains 37 percent of China's population, into 1,281 equally sized grid cells of $0.25 \times 0.25$ degrees (approximately $28 \times 28$ kilometers). In a first step, we use historical census data from Bielenstein (1987), available for the years $2 \mathrm{CE}, 140 \mathrm{CE}, 742 \mathrm{CE}$ and $1102 \mathrm{CE}$, to investigate how the completion of the Sui Canal influenced the spatial distribution of population. To quantify the effects, we employ both an OLS and a 2SLS-IV approach. For the latter, we exploit the fact that a main motivation for building the canal was to create a direct connection between important centers and instrument the actual path of the canal with straight lines between the central 
nodes. Irrespective of the estimation approach, we find that population in grid cells along the canal increased substantially after the completion of the transport network compared to regions with no direct access. The fact that we do not find any effect of the canal on population in census years prior to its construction (i.e., in year 2 and 140) supports the view that our estimates specifically capture canal-related effects. The point estimate in our preferred IV setup indicates that population numbers increased by 0.6 standard deviations in regions that were connected to the canal. The magnitude of the effect is consistent with historical accounts that suggest that the completion of the canal reduced transport costs along its course and lead to an increase in long-distance domestic trade. This, in turn, enabled product specialization and boosted economic growth (Berger 1988, p.31), Liu (2015, Chapter 4)).

At the end of the 12th century CE large parts of the western section of the Sui Canal were destroyed during the Mongol invasion and have since never been rebuilt. In our analysis, we exploit this fact to assess the degree of persistence in the spatial distribution and economic activity over the very long run. We find that grid cells located along the no longer existing Sui Canal are still significantly more populated in 2010 compared to cells that were never connected to the canal. The effect on current-day population is about 60 percent of its historical magnitude. This indicates that the transport-access-driven shift in population concentration is extraordinarily persistent and only slowly dissipates over time. In contrast to the positive effect on population, we find that GDP per capita is lower in regions located along the defunct sections of the canal. A potentially important explanation for this finding is that non-coastal regions, including regions previously connected to the Sui Canal, have been disadvantaged in terms of public investments since the initiation of the Open Door Policy in 1978 (e.g., Zhang and Fan, 2004). Since then, proximity to the coast has been one of the main locational determinants of investment and modern industrial development (e.g., Zhang and Fan, 2004). We provide suggestive evidence that, in fact, public expenditure is not proportional to population numbers in regions previously intersected by the Sui Canal. Overall, our study shows that the completion of the Sui Canal strongly influenced the spatial distribution of population in historical times. This effect is still detectable almost a millennium after its original advantages ceased to exist. Our results further suggest that when (the distribution of) population only adapts slowly (or not at all) to a change in the value of locational fundamentals, this can result in a negative income per capita effect in areas that are densely populated due to previous locational advantages. An important note pertains to the generalizability of our results. China, with its long history of centralized 
rule, represents a very specific case. Adaption processes in countries with fewer restrictions on factor mobility and less interventionistic governments may be different.

Our paper directly contributes to the literature that lies at the intersection of economic geography and long-run economic development (e.g., Krugman (1999); Henderson et al. (2001). While many studies stress the importance of time-invariant geographic fundamentals in explaining the spatial distribution of population and economic activity (e.g., Davis and Weinstein (2002); Rappaport and Sachs (2003); Bosker et al. (2007); Miguel and Roland (2011)), there are a number of papers that highlight that the value of locational fundamentals may change over time. This implies that the same geographical characteristics influences economic productivity differently at different times. For example Nunn and Qian (2011) and Henderson et al. (2018a) document that technological progress can change the value of locational fundamentals which subsequently influences the spatial distribution of population. The results of Michaels and Rauch (2013) further show that a change in the value of the locational fundamentals can lead to a sub-optimal spatial equilibria if the distribution of population is inert.

Particularly closely related to our paper are the studies that document that historical (man-made) shocks can have persistent effects on the spatial distribution of population as well as regional inequality in economic development (e.g., Nunn (2008); Dell (2010); Redding et al. (2010); Bleakley and Lin (2012); Nunn and Puga (2012); Michalopoulos and Papaioannou (2013)). In recent work Jedwab et al. (2017) and Jedwab and Moradi (2016) show that population is still disproportionately concentrated in areas which were once connected to transport networks that no longer exist. Compared to these studies, our analysis covers a much longer time span.

Our paper further complements the literature by focusing on China, rather on than the Western world or Sub-Saharan Africa. In that regard, our work directly speaks to the papers that investigate the effect of modern-day infrastructure projects on local development in China (e.g., Faber (2014); Banerjee et al. (2012); Baum-Snow et al. (2017)). Finally, our study also directly speaks to literature that documents frictions in migration can reduce welfare (e.g., Desmet et al. (Forthcoming) or Munshi and Rosenzweig (2016)).

The remainder of the paper is structured as follows: In the next section, we provide background information regarding the construction of the Sui Canal. Section 3 presents our empirical strategy. The data are presented in Section 4 along with the descriptive statistics. The regression results are discussed in Section 5 , Section 6 concludes. 


\section{Background}

China's long standing reliance on water control for irrigation and transport is well documented (e.g., Chi (1970), Needham et al. (1971, Chapter 28)). The earliest irrigation systems date back as far as the 8th century BCE, while larger (irrigation) canals had been constructed by the 3rd century BCE (Needham et al., 1971, p.269, p.284). While these projects were impressive from an engineering point of view, their impact was locally confined. This changed in the 7th century CE, when, under the Sui dynasty (581-618), a canal of more than 2,500 kilometers was built that connected North and South China via its capitals, Xi'an and Luoyang. ${ }^{1}$ The Y-shaped path of the Sui Canal is depicted in Figure 1, panel (a). The figure also illustrates which region of China our empirical analysis focuses on.

The central node of the Sui Canal was located at Luoyang/Zhengzhou from where one branch of the canal ran southwards to Xuyi via Kaifeng and then from Huai'an to Hangzhou. The second branch followed a northward path towards Tianjing and Bejing via Daming. The southern leg, completed in $605 \mathrm{CE}$, was constructed to establish a direct link between the capital region and the highly fertile lower Yangtze region which had become a key economic area and the primary supplier of grain (Needham et al., 1971, p.307). The northern leg was built primarily for military strategy reasons. It facilitated the supply of armies needed to protect the northern and north-eastern regions of the empire which were under constant threat from nomadic people (Wright (1979), Berger (1988, p.30)). The northern section was completed in the year $610 \mathrm{CE}$ and thereby established a direct link between North and South China. Both legs of the canal were constructed over a period of a few years following three centuries of continued warfare and turmoil. At least five million workers were mobilized for construction work (Needham et al. (1971, p.308), Berger (1988, p.29)).$^{2}$ The fact that the main purpose of the canal was to connect the capital region directly with economically and strategically important endpoints suggests that the regions along the Sui Canal were not characterized by pre-existing differences in population concentration. In our empirical analysis, we will provide evidence for the plausibility of this notion.

Under the successors of the Sui, the Tang dynasty (618-907) and the (Northern) Song

\footnotetext{
${ }^{1}$ The names of cities mentioned in this section often have different spellings and, in some cases, changed over time. We will refer to the cities by their current names throughout our study.

${ }^{2}$ While the Sui Canal integrated a number of smaller existing canals into its network, these sections had to be substantially modified and enlarged. Additionally, large sections of the canal were truly new enterprises (Needham et al. 1971, p.306ff.).
} 
(a)

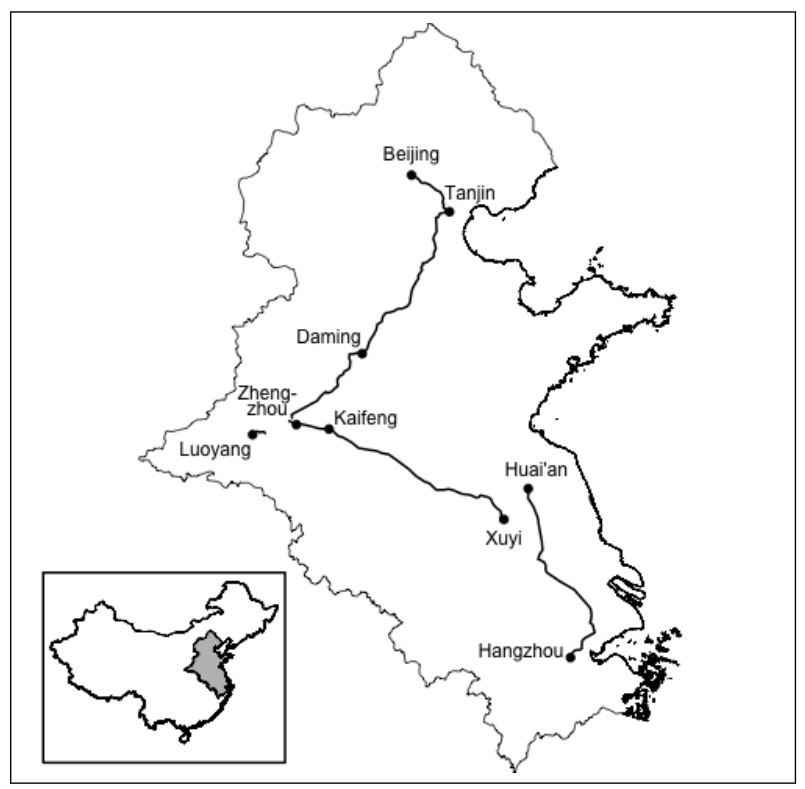

(b)

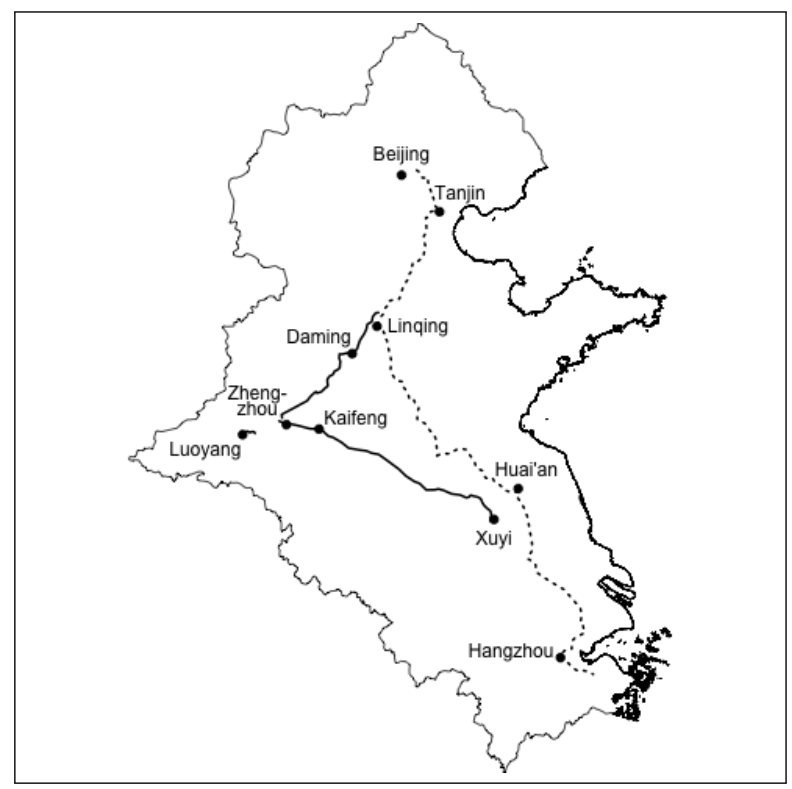

Figure 1: Panel (a) depicts the course of the Sui Canal (bold line). Panel (b) depicts the course of the Grand Canal (dotted line), as well as the section of the Sui Canal that fell out of use in the 12th century (bold line).

dynasty (960-1279), the use of the canal was intensified and was an important determinant of the economic prosperity that characterized this era. The completion of the canal ledfor the first time in Chinese history - to the emergence of a national market. This enabled product specialization and fostered economic development (e.g., Xiong 2006, Chapter 4), Liu (2015, Chapter 4)). The benefits were particularly pronounced in regions directly adjacent to the canal. The high level of trade activity induced economic growth, led to the establishment of trading towns and a shift in population concentration towards the regions situated along the canal (e.g., Berger (1988, p.31), Liu (2015, p.92). Documenting the central role of the canal is the fact that that by 1077, taxes collected from cities along the canal had become one of the primary income sources of the Chinese state (Liu, 2015, p.81). It is important to note that the canal also stimulated (additional) public investment. For example, an imperial road was constructed along its banks (Needham et al., 1971, p.308), granaries were moved to the canal (Needham et al., 1971, p.310) and post offices were established alongside the waterway (Ebrey, 1996, p.116). Our subsequent estimates should therefore be interpreted as the overall canal-related effect. This effect can work though multiple channels, including (but not restricted to) direct waterway-networkinduced reductions in transport costs, co-localized public investments and increased labor 
demand related to the maintenance of the canal (e.g., Berger (1988, p.31 f.) or Marks (2011, p. 119 f.)).

Trade along the Sui Canal came to an end with the Mongol invasion during the 12th century. Parts of the western section of the canal were destroyed in 1126 partly by the Song soldiers themselves in futile attempts to halt the progress of the Mongols (Needham et al., 1971, p.311). In 1280, the Mongol Yuan dynasty ultimately defeated the Chinese and subsequently moved the capital north to Beijing. In order to link the new center of political power to the economic center of the lower Yangtze region, the Yuan chose to construct a new, direct North-South canal, rather than to rebuild the westerly parts of the Sui Canal. The course of the new canal, known as the Grand Canal, is depicted in Figure 1 . panel (b). As can be seen, the southern section of the Sui Canal was integrated into the new canal network. In the north, the Yuan Canal also closely followed the original course of the Sui Canal. Between Huai'an and Linqing, however, an entirely new section was built. The western section of the Sui Canal, depicted as a bold line in panel (b) of Figure 1. was never rebuilt for the use of water transport after it had fallen out of use in the 12th century (Berger, 1988, p.32). The regions along this section of the Sui Canal consequently lost their original transport-cost-related locational advantage more than 800 years ago.

While access to the inland transport network was historically an important determinant of economic development, proximity to the coast has become a dominant locational fundamental in more recent times. Since the start of the Open Door Policy in 1979, (industrial) investments, domestic as well as foreign, have been concentrated in coastal regions due to preferential policy treatment as well as the regions' advantageous location allowing direct access to the world markets via ocean-borne trade (e.g., Démurger et al. (2002), Lemoine et al. (2015)).

\section{Empirical Strategy}

To investigate the effect of the Sui Canal on the spatial distribution of population and economic activity, we employ an OLS as well an instrumental variable approach. The two approaches are outlined below. 


\section{Ordinary Least Squares Approach}

The basis for our empirical analysis is the following cross-sectional OLS regression model:

$$
p_{c, t}=\gamma S_{c, t}+\boldsymbol{\beta}^{\prime} \mathbf{X}_{c, t}+\varepsilon_{c, t}
$$

where the dependent variable $p_{c, t}$ represents total population living within a given grid cell $c$ in year $t t^{3}$ Our main explanatory variable is the indicator variable $S_{c, t}$ which takes the value one if a grid cell is intersected by the Sui Canal and zero otherwise. In all regressions, we control for a host of climatic and geographical variables. These are represented by the vector $\mathbf{X}_{c, t}$ and include: (log) mean temperature, (log) mean precipitation, (log) elevation, (log) ruggedness, $(\log )$ agricultural potential, $(\log )$ rice suitability, latitude, $(\log )$ land mass area, (log) distance to coastline, as well as separate dummy variables indicating whether a cell is intersected by a river, lake or coastline. Due to its particular importance with respect to agricultural development as well as transport, we include a separate indicator variable for the connectedness with the Yellow River. Similarly, we also define a dummy variable for the connectedness to the Yangtze River and river delta. In all our regressions, we control for $2 \times 2$ degree 'super grid' fixed effects to account for any additional unobserved regional differences in geographic, climatic or institutional characteristics. The inclusion of these fixed effects implies that the identifying variation is only generated by differences within the $2 \times 2$ degree grid cells. This mitigates concerns related to omitted variables ${ }^{4}$

We address the possibility that the course of the Sui Canal was endogenous with respect to population concentration in multiple steps. First, we exclude grid cells containing terminals and nodes as well as their neighboring cells from our analysis. Second, we always control for the euclidean distance to the nodes. Third, we develop an instrumental variable approach as described next.5

\section{Instrumental Variable Approach}

Based on the fact that the Sui Canal was built as a direct link between important centers (see Section 2), we construct an instrument by identifying which grid cells lie on a straight line between terminals and nodes.6 ${ }^{6}$ To the north, the straight line connects Luyoang to

\footnotetext{
${ }^{3}$ In the second part of our analysis, we additionally use grid-cell level GDP as outcome variable.

${ }^{4}$ The issue of omitted variables is discussed in more detail in Section 5

${ }^{5}$ The instrumental variable approach also mitigates issues related to measurement errors, e.g., originating from imprecise geocoding, in the course taken by the Sui Canal.

${ }^{6} \mathrm{~A}$ similar identification strategy is, for example, also employed in Faber (2014) and Hornung (2015).
} 
Beijing via Daming and Tianjin. In the south, the straight line runs from Luyoang via Kaifeng, Xuyi and Huai'an to Hangzhou. The instrument, along with the course of the Sui Canal, is depicted in Figure A.1.

Formally, the first stage regression can be represented as:

$$
S_{c, t}=\gamma_{1} S L_{c, t}+\boldsymbol{\beta}_{1}^{\prime} \mathbf{X}_{c, t}+\xi_{c, t}
$$

where $S_{c, t}$ represents the dummy variable for the intersection with the Sui Canal and $S L_{c, t}$ is our straight line instrument. The second stage regression is accordingly:

$$
p_{c, t}=\gamma_{2} \widehat{S_{c, t}}+\boldsymbol{\beta}_{2}^{\prime} \mathbf{X}_{c, t}+\zeta_{c, t}
$$

The predicted values obtained from the first stage regression are symbolized by $\widehat{S_{c, t}}$. The set of controls $\left(\mathbf{X}_{c, t}\right)$ contains the same variables as in the OLS setup. Regarding inference, we cluster the standard errors at $2 \times 2$ degree grid cells in all regression (cf., Motamed et al. (2014); Dincecco and Onorato (2016); Iyigun et al. (2017)). The identifying assumption underlying our regression analysis is that, conditional on the control variables, the (instrumented) dummy variable for the Sui Canal captures effects that are solely due to the establishment of the canal and is unrelated to any other factors in the error term. There are several threats to the validity of this assumption; these are discussed in Section 5.

\section{Data and Descriptive Analysis}

This section provides an overview of the data used in the empirical analysis along with a descriptive analysis thereof.

\subsection{Data}

In our study, we focus on the two physiographic macroregions that are intersected by the Sui Canal (see Figure 1).7 This restriction in geographic scope reduces the risk of comparing fundamentally different areas.

\footnotetext{
${ }^{7}$ Macroregions delineate different areas according to geographical features that structured the socioeconomic landscape of China prior to the advent of modern transportation (Skinner, 1977). The macrozones included in the analysis are North China and the Lower Yangzi. In 2010, this region was home to 37 percent of China's total population, while covering 9 percent of the total area.
} 
For our empirical analysis, we divide the area encompassed by the two macrozones into 1,281 equally sized grid cells of $0.25 \times 0.25$ degrees. As mentioned in Section 3, we drop all grid cells that contain terminal points or nodes as well as their respective neighboring cells 8 For all grid cells, we compute the mean temperature, precipitation, elevation and ruggedness. The underlying data are drawn from Hijmans et al. (2005).9 To capture the cells' accessibility by waterways, we construct separate dummy variables for the intersection with a navigable river, lake and coastline. These data are extracted from Www.naturalearthdata.com. Additionally, we compute the distance of a grid cell's center to the nearest coastline as well as the center's latitude. To account for their central importance with respect to transport and agricultural production, we define separate dummy variables that indicate whether a grid cell is intersected by the Yangtze or the Yellow River. The course of the Yellow River has changed several times. These changes are documented in the Atlas of the Yellow River Watershed and are available as shapefiles from http://worldmap.harvard.edu. In our regressions, we include separate dummies for the interaction with past and contemporaneous courses of the river. The data with respect to the course of the Yangtze River is extracted from the Harvard WorldMap. The grid cells' agricultural potential is captured by the index developed in Galor and Özak (2015), rice suitability by the index provided in IIASA/FAO (2012). We construct our main explanatory variable using information on the course of the Sui Canal, geocoded by Peter K. Bol and available at Harvard WorldMap. This variable takes the value one if a grid cell is intersected by the canal and zero otherwise. Similarly, we define an indicator variable that takes the value one if a cell is intersected by the section of the Sui Canal that fell into disrepair after the 12th century. Our dependent variables are constructed from multiple sources. Information with respect to the historical spatial distribution of China's population originates from Bielenstein (1987). Based on census data, this source provides dot maps representing the distribution of the population for various years (whereby a dot represents 25,000 individuals). The census quality varies considerably. We use censuses for which population counts are reliable according to Bielenstein (1987). This applies to the censuses conducted in the years $2 \mathrm{CE}, 140 \mathrm{CE}, 742 \mathrm{CE}$ and $1102 \mathrm{CE}$ (Bielenstein, 1987, chapter 2). Peter K. Bol geocoded the censuses of the years 2, 742 and 1102 and

\footnotetext{
${ }^{8}$ Specifically, we drop the grid cells (as well as their neighbors) in which the following cities are located: Beijing, Daming, Hangzhou, Huai'an, the Kaifeng-Zhengzhou-Luoyang capital region, Tianjin and Xuyi.

${ }^{9}$ The temperature and precipitation data are reported as monthly means over the period 1950-2000. An implicit assumption in our analysis is therefore, that the relative position of a grid cell in the temperature (precipitation) distribution has remained constant over time; i.e., the modern day data is a good proxy for the past values.
} 
made them available through Harvard WorldMap. We augment these data by geocoding the census of 140. For all years, we aggregate the 'dot-level data' at the grid-cell level by counting the number of dots that fall within each $0.25 \times 0.25$ degree grid cell.

Data on the population distribution for the year 2010 is extracted from Gaughan et al. (2016). This data source provides high-resolution population data (approximately at $100 \times 100$ meter grids) which was validated using population counts. For our analysis, we aggregate the data to the $0.25 \times 0.25$ degree grid-cell level. Finally, we use the GDP estimates (measured in ten thousand RMB) for the year 2010 derived in Huang et al. (2014) and provided at a spatial resolution of $1 \times 1$ kilometers (which we aggregate to $0.25 \times 0.25$ degrees by computing the sum). Throughout our analysis, we standardize our dependent variables, i.e., build z-scores. The use of standardized values rather than raw numbers facilitates the comparison of coefficient estimates across the various time periods (e.g., Jedwab and Moradi (2016); Jedwab et al. (2017)).10

\subsection{Descriptive Analysis}

Table 1 provides the summary statistics for our key variables. The variable 'Sui Canal' represents the dummy variable that takes the value one if a grid cell was ever intersected by the Sui Canal, and zero otherwise. As shown, 3.3 percent of the cells had direct access to the canal. The percentage of grid cells that were adjacent to the section of the canal that fell into disrepair after the 12 th century is 1.2. Grid-cell level population numbers and GDP vary substantially; this will be exploited in our empirical analysis.

Table 1: Descriptive Statistics Key Variables

\begin{tabular}{lccccc}
\hline Variable & Mean & Std. Dev. & Min. & Max. & Obs. \\
\hline Sui Canal & 0.033 & 0.178 & 0 & 1 & 1281 \\
Sui Canal Destroyed Section & 0.012 & 0.108 & 0 & 1 & 1281 \\
Population 2 & 0 & 1 & -0.887 & 5.182 & 1281 \\
Population 140 & 0 & 1 & -0.670 & 5.171 & 1281 \\
Population 742 & 0 & 1 & -0.794 & 7.311 & 1281 \\
Population 1102 & 0 & 1 & -0.772 & 5.170 & 1281 \\
Population 2010 & 0 & 1 & -0.894 & 16.071 & 1281 \\
GDP 2010 & 0 & 1 & -0.765 & 9.449 & 1281 \\
GDP per capita 2010 & 0 & 1 & -0.7257 & 22.286 & 1281 \\
\hline
\end{tabular}

\footnotetext{
${ }^{10}$ When using raw numbers, coefficient sizes change 'mechanically' with overall population levels. This is not the case when variables are standardized.
} 
Figure 2 provides descriptive evidence that the construction of the Sui Canal lead to an increase in population around the canal and that this effect is detectable up to the present day. Panel (a) depicts the population distribution in year 2 CE, i.e., before construction. The darker the shading, the more populated the grid cell. While there is no marked population concentration in the vicinity of the (not yet constructed) Sui Canal, this changes in the year 742. A clear positive association between a cell's total population and the course of the canal is detectable (panel (b)). Visual inspection of panel (c) further suggests that the population concentration along the Sui Canal persists to the current era. In the next section, we will formally test the existence of these effects.

(a)

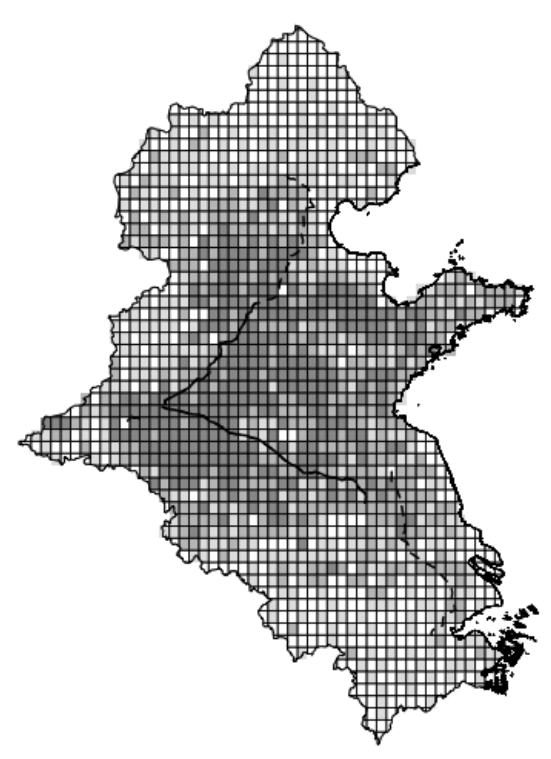

(b)

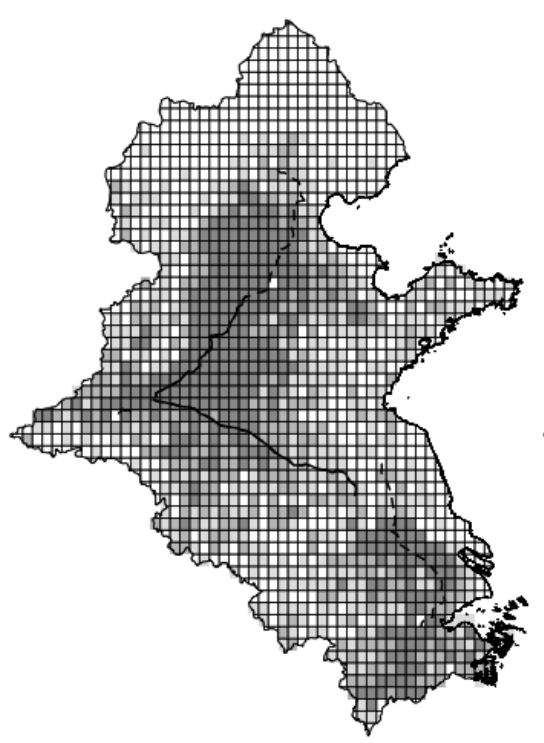

(c)

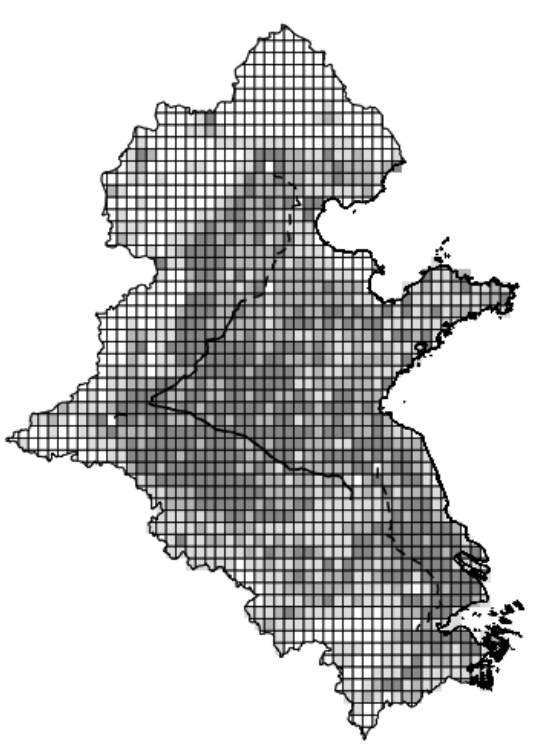

Figure 2: Panel (a) depicts the spatial distribution population in the year 2 CE. Panel (b) depictis it in the year $742 \mathrm{CE}$, panel (c) in the year $2010 \mathrm{CE}$. The darker the shading, the higher is is grid-cell level population.

A general concern for our the validity of our analysis is that grid cells along the canal are structurally different from other regions. In this case, our estimates could capture these structural differences rather than canal-specific effects. To address this issue, we investigate whether there are - conditional on $2 \times 2$ degree grid cell fixed effects - observable differences in the included control variables. Column (1) of Table 2 depicts the difference in means between grid cells that are intersected by the canal and those that are not. In column (2) we compare means between grid cells that are intersected by our straight line instrument to means of other cells 10

\footnotetext{
${ }^{11}$ All variables are standardized to a mean of zero and a standard deviation of one.
} 
Table 2: Differences in Means Control Variables

\begin{tabular}{|c|c|c|c|c|c|c|}
\hline & \multicolumn{3}{|c|}{ Sui Canal } & \multicolumn{3}{|c|}{ Sui Canal Destroyed Section } \\
\hline & $\begin{array}{c}\text { Intersected } \\
\text { by Canal vs } \\
\text { Non-Intersected }\end{array}$ & $\begin{array}{c}\text { Intersected } \\
\text { by IV vs } \\
\text { Non-Intersected }\end{array}$ & Obs. & $\begin{array}{c}\text { Intersected } \\
\text { by Canal vs } \\
\text { Non-Intersected }\end{array}$ & $\begin{array}{c}\text { Intersected } \\
\text { by IV vs } \\
\text { Non-Intersected }\end{array}$ & Obs. \\
\hline & $(1)$ & $(2)$ & & $(3)$ & $(4)$ & \\
\hline Precipitation & $\begin{array}{l}-0.003 \\
(0.060)\end{array}$ & $\begin{array}{l}-0.064 \\
(0.053)\end{array}$ & 1,281 & $\begin{array}{c}0.051 \\
(0.077)\end{array}$ & $\begin{array}{c}0.048 \\
(0.081)\end{array}$ & 1,254 \\
\hline Temperature & $\begin{array}{l}0.111^{*} \\
(0.062)\end{array}$ & $\begin{array}{c}0.024 \\
(0.038)\end{array}$ & 1,281 & $\begin{array}{l}0.161^{*} \\
(0.091)\end{array}$ & $\begin{array}{c}0.105 \\
(0.062)\end{array}$ & 1,254 \\
\hline $\begin{array}{l}\text { Caloric } \\
\text { suitability }\end{array}$ & $\begin{array}{l}-0.031 \\
(0.081)\end{array}$ & $\begin{array}{l}-0.043 \\
(0.066)\end{array}$ & 1,281 & $\begin{array}{l}-0.066 \\
(0.137)\end{array}$ & $\begin{array}{l}-0.004 \\
(0.162)\end{array}$ & 1,254 \\
\hline $\begin{array}{l}\text { Rice } \\
\text { suitability }\end{array}$ & $\begin{array}{l}-0.091 \\
(0.181)\end{array}$ & $\begin{array}{l}-0.236 \\
(0.212)\end{array}$ & 1,281 & $\begin{array}{c}0.000 \\
(0.000)\end{array}$ & $\begin{array}{c}0.000 \\
(0.000)\end{array}$ & 1,254 \\
\hline Elevation & $\begin{array}{c}-0.353^{* * *} \\
(0.111)\end{array}$ & $\begin{array}{l}-0.133 \\
(0.099)\end{array}$ & 1,281 & $\begin{array}{l}-0.388 \\
(0.230)\end{array}$ & $\begin{array}{l}-0.172 \\
(0.151)\end{array}$ & 1,254 \\
\hline Ruggendess & $\begin{array}{c}-0.592^{* *} \\
(0.234)\end{array}$ & $\begin{array}{l}-0.286 \\
(0.194)\end{array}$ & 1,281 & $\begin{array}{l}-0.454 \\
(0.429)\end{array}$ & $\begin{array}{l}-0.140 \\
(0.342)\end{array}$ & 1,254 \\
\hline River & $\begin{array}{l}-0.129 \\
(0.082)\end{array}$ & $\begin{array}{c}0.061 \\
(0.264)\end{array}$ & 1,281 & $\begin{array}{l}-0.152 \\
(0.142)\end{array}$ & $\begin{array}{c}-0.153 \\
(0.138)\end{array}$ & 1,254 \\
\hline Lake & $\begin{array}{c}0.739 \\
(0.499)\end{array}$ & $\begin{array}{c}1.004 \\
(0.670)\end{array}$ & 1,281 & $\begin{array}{c}0.000 \\
(0.000)\end{array}$ & $\begin{array}{c}0.000 \\
(0.000)\end{array}$ & 1,254 \\
\hline $\begin{array}{l}\text { Yangtze } \\
\text { River }\end{array}$ & $\begin{array}{c}-0.196^{*} \\
(0.109)\end{array}$ & $\begin{array}{l}-0.221 \\
(0.136)\end{array}$ & 1,281 & $\begin{array}{c}0.000 \\
(0.000)\end{array}$ & $\begin{array}{c}0.000 \\
(0.000)\end{array}$ & 1,254 \\
\hline $\begin{array}{l}\text { Yangtze } \\
\text { Delta }\end{array}$ & $\begin{array}{c}0.216 \\
(0.307)\end{array}$ & $\begin{array}{l}-0.137 \\
(0.127)\end{array}$ & 1,281 & $\begin{array}{c}0.000 \\
(0.000)\end{array}$ & $\begin{array}{c}0.000 \\
(0.000)\end{array}$ & 1,254 \\
\hline $\begin{array}{l}\text { Yellow } \\
\text { River }\end{array}$ & $\begin{array}{c}0.077 \\
(0.277)\end{array}$ & $\begin{array}{c}0.256 \\
(0.406)\end{array}$ & 1,281 & $\begin{array}{l}0.745^{*} \\
(0.376)\end{array}$ & $\begin{array}{c}0.875 \\
(0.857)\end{array}$ & 1,254 \\
\hline $\begin{array}{l}\text { Coastline } \\
\text { intersection }\end{array}$ & $\begin{array}{l}-0.028 \\
(0.021)\end{array}$ & $\begin{array}{l}-0.034 \\
(0.032)\end{array}$ & 1,281 & $\begin{array}{c}0.000 \\
(0.000)\end{array}$ & $\begin{array}{c}0.000 \\
(0.000)\end{array}$ & 1,254 \\
\hline $\begin{array}{l}\text { Distance } \\
\text { coastline }\end{array}$ & $\begin{array}{l}-0.017 \\
(0.096)\end{array}$ & $\begin{array}{c}0.037 \\
(0.159)\end{array}$ & 1,281 & $\begin{array}{l}-0.002 \\
(0.042)\end{array}$ & $\begin{array}{c}0.022 \\
(0.033)\end{array}$ & 1,254 \\
\hline Latitude & $\begin{array}{l}-0.010 \\
(0.064)\end{array}$ & $\begin{array}{c}0.046 \\
(0.066)\end{array}$ & 1,281 & $\begin{array}{l}-0.059 \\
(0.083)\end{array}$ & $\begin{array}{l}-0.065 \\
(0.087)\end{array}$ & 1,254 \\
\hline
\end{tabular}

Notes: ${ }^{*} p<0.10,{ }^{* *} p<0.05,{ }^{* * *} p<0.01$. Table depicts differences in means conditional on $2 \times 2$ degree grid fixed effects. Standard errors clustered at $2 \times 2$ grid cells. All variables represent $z$-scores.

Looking at statistically significant differences in means in column (1), we observe that cells along the Sui Canal lie at lower elevation and are characterized by less rugged terrain. Additional differences are observable in temperature as well as the probability of being intersected by the Yangtze River. These differences in observables suggest that the course of the canal was (partly) influenced by local geographic conditions. Reassuringly, however, there are no statistically significant differences in means when we compare grid cells that intersected by the straight line instrument with other cells. This indicates that our instru- 
mental variable approach helps avoid selection effects. In Section 5, we additionally show that unobservables - a concern not fully alleviated by the lack of differences in means - are unlikely to invalidate our findings.

Later, when analyzing the effects of the Sui Canal on present-day outcomes, we will focus on the section of the canal that fell into disrepair after the 12th century, i.e., the part that was not integrated into the Grand Canal (see Figure 1, panel (b)). In columns (3)-(4) we check whether there are differences in observables between these cells and grid cells that were never connected to the waterway system. ${ }^{12}$ The pattern of results is similar compared to columns (1)-(2). Crucially, the geographic characteristics of the grid cells intersected by the straight line instrument do not differ systematically from other cells.

\section{Results}

In the following, we first show that the construction of the Sui Canal led to an increase in population in regions directly connected to the new transport network. In a second part, we then investigate to what extent this effect is still reflected in current-day population numbers and economic activity.

\subsection{Sui Canal Construction and Population Concentration in His- torical Era}

We start our formal analysis by running the OLS regression model (1) separately for each year for which historical census data are available. The results are depicted in Table 3 . Columns (1)-(2) analyze the effect in pre-construction years. For both, year 2 and 140, the point estimates of the Sui Canal are close to zero and statistically non-significant. This documents that cells later connected to the transport network were not more populous in census years prior to construction. For the year 742-approximately 130 years after completion - on the other hand, we find that population numbers are significantly higher in grid cells that are intersected by the canal (column (3)). The point estimate of 0.789 depicted in column (3) implies that population in grid cells along the Sui Canal was 0.789

\footnotetext{
${ }^{12}$ We drop all cells that are intersected by the section of the Sui Canal that is still in use today to avoid including 'canal cells' in the control group.
} 
standard deviations higher relative to cells that were not connected to the canal.13 Evaluated at the sample mean, this corresponds to a doubling of the population. The estimate is similar for the year 1102 (column (3)), suggesting that there was limited canal-induced growth during the time period $742-1102$.

Table 3: Sui Canal and Population Concentration in Historical Era

\begin{tabular}{|c|c|c|c|c|c|c|c|c|}
\hline \multirow[t]{3}{*}{ Dependent Variable } & \multicolumn{8}{|c|}{ Total Population $(\mathrm{SD})_{t}$} \\
\hline & \multicolumn{4}{|c|}{ OLS } & \multicolumn{4}{|c|}{ 2SLS-IV } \\
\hline & (1) & $(2)$ & $(3)$ & $(4)$ & $(5)$ & $(6)$ & (7) & $(8)$ \\
\hline \multirow[t]{2}{*}{ Sui Canal } & $\begin{array}{l}-0.021 \\
(0.184)\end{array}$ & $\begin{array}{c}-0.031 \\
(0.158)\end{array}$ & $\begin{array}{c}0.789^{* *} \\
(0.323)\end{array}$ & $\begin{array}{c}0.925^{* *} \\
(0.345)\end{array}$ & $\begin{array}{l}-0.005 \\
(0.397)\end{array}$ & $\begin{array}{l}-0.228 \\
(0.207)\end{array}$ & $\begin{array}{c}0.668^{* * *} \\
(0.249)\end{array}$ & $\begin{array}{c}0.634^{* * *} \\
(0.168)\end{array}$ \\
\hline & & & & & \multicolumn{4}{|c|}{ First Stage Regression: Sui Canal } \\
\hline Straight line & & & & & $\begin{array}{c}0.597^{* * *} \\
(0.166)\end{array}$ & $\begin{array}{c}0.601^{* * *} \\
(0.169)\end{array}$ & $\begin{array}{c}0.601^{* * *} \\
(0.169) \\
\end{array}$ & $\begin{array}{c}0.606^{* * *} \\
(0.171)\end{array}$ \\
\hline Year of Census (LHS) & 2 & 140 & 742 & 1102 & 2 & 140 & 742 & 1102 \\
\hline Climate Controls & yes & yes & yes & yes & yes & yes & yes & yes \\
\hline Geography Controls & yes & yes & yes & yes & yes & yes & yes & yes \\
\hline $2 \times 2$ degree $\mathrm{FE}$ & yes & yes & yes & yes & yes & yes & yes & yes \\
\hline Kleibergen-Paap F-statistic & & & & & 12.93 & 12.68 & 12.68 & 12.59 \\
\hline Obs. & 1,281 & 1,281 & 1,281 & 1,281 & 1,281 & 1,281 & 1,281 & 1,281 \\
\hline
\end{tabular}

Notes: ${ }^{*} p<0.10,{ }^{* *} p<0.05,{ }^{* * *} p<0.01$. Standard errors clustered at $2 \times 2$ degree grid cells reported in parentheses. 'Year of Census (LHS)' indicates the census to which the LHS variable corresponds. Climate controls include (log) precipitation and $(\log )$ temperature. Geography controls include latitude, (log) distance to coast, (log) elevation, (log) ruggedness, (log) area of grid cell, (log) agricultural suitability, and (log) rice suitability. Furthermore, the following geography-related dummy variables are included: Coastline intersection, Yangtze River, Yangtze Delta, separate dummy variables for the intersection with the past and contemporaneous course of the Yellow river, access to a river, and access to a lake. Regressions in all columns with macroregion and $2 \times 2$ degree grid-cell fixed effects. 'Kleibergen-Paap' represents the first-stage KleibergenPaap F-statistic for the excluded instrument.

As outlined above, a major concern is that the course of the Sui Canal was influenced by local characteristics (observed or unobserved) which themselves could have influenced population numbers between 140 and 742 (see e.g., Table 2, column (1)). To mitigate this concern, we employ the straight line instrumental variable approach in columns (5)-(8). As documented by the statistically highly significant first-stage coefficients as well as the Kleibergen-Paap F-statistic for the excluded instrument of more than 12, our instrument predicts the actual course of the Sui Canal well ${ }^{14}$ This suggests that the IV estimates are unlikely to be biased by weak instruments. The pattern of the IV regression results is

\footnotetext{
${ }^{13}$ The fact that there is no effect in the years prior to completion, implies that the level effects can also be interpreted as growth effects relative to the pre-construction years 2 and 140 .

${ }^{14}$ Note that the values of the F-statistic vary slightly over the years. This is due to the fact that we include separate dummies for the interaction with past and contemporaneous courses of the Yellow River. Including a time-invariant set of controls (e.g., dropping all Yellow River indicators or controlling for all courses in all regressions) leaves our estimates unchanged.
} 
qualitatively equivalent to the OLS approach. The effect of the Sui Canal on population numbers is observable only in census years after completion. Compared to the OLS regressions, the IV approach produces somewhat smaller coefficients ${ }^{15}$ For the year 1102, where we observe the largest difference between the coefficients, the IV point estimate is 0.634 while the OLS counterpart is 0.925. This suggests that path of the Sui Canal was partly influenced by local characteristics, making the IV procedure the preferred approach.

As mentioned earlier, we will focus on the section of the canal that fell into disrepair after the 12th century, i.e., the part that was not integrated into the Grand Canal (see Figure 1. panel (b)) when we look at current-day outcomes in Section 5.2. To document that the results presented in Table 3 also apply to this section of the Sui Canal, we create a dummy variable that takes the value one if a grid cell was intersected by the now-defunct part of the canal and zero otherwise. We then re-run the regressions of Table $3{ }^{16}$ As shown in Table 4, the results remain qualitatively unchanged. There is a marked increase in population within grid cells connected to the Sui Canal. However, this effect emerges only after the completion of the canal. The magnitude of the IV estimates presented in Table 3 (columns (5)-(8)) are comparable to the point estimates depicted in Table $4{ }^{17}$

Overall, the results presented above provide empirical support for the historical accounts that describe that the flourishing canal trade lead to a disproportionate increase in population and economic activity along the course of the new transport network (see Section 2]. There are, however, a number of concerns related to our identification strategy. One issue is that, while we can test for pre-trends between 2 and $140 \mathrm{CE}$, we do not observe the spatial distribution of population in years immediately before (or after) the completion of the canal. Other events could have occurred during the time period 140-742 that were systematically correlated with the course of the Sui Canal and confound our results. We argue that this is unlikely to be the case due to the fact that the canal was constructed in a very short period of time following centuries of turmoil and warfare. Between 220 and 581 , the formerly unified empire was fragmented and large parts of this infrastructure was destroyed (e.g., Needham et al. (1971, p.31)). Only under the Sui dynasty were planning

\footnotetext{
${ }^{15}$ The differences are, however, statistically indistinguishable. The p-value of the test for coefficient equality between column (1) and (5) is 0.97 , between column (2)-(6) 0.45 , between column (3)-(7) 0.30 , and between column (4)-(8) 0.45 .

${ }^{16}$ We drop all cells that are intersected by the section of the Sui Canal that is still in use today to avoid including 'canal cells' in the control group. The results remain very similar if we use the full sample.

${ }^{17}$ The differences between the point estimates of in Tables 3 and 4 are not statistically significant at conventional confidence levels. The p-values of coefficient equality for columns (1)-(8) are: $0.25,0.97$, $0.56,0.79,0.54,0.95,0.80$, and 0.46 .
} 
Table 4: Sui Canal Destroyed Section and Population Concentration in Historical Era

\begin{tabular}{|c|c|c|c|c|c|c|c|c|}
\hline \multirow[t]{3}{*}{ Dependent Variable } & \multicolumn{8}{|c|}{ Total Population $(\mathrm{SD})_{t}$} \\
\hline & \multicolumn{4}{|c|}{ OLS } & \multicolumn{4}{|c|}{ 2SLS-IV } \\
\hline & $(1)$ & $(2)$ & $(3)$ & $(4)$ & (5) & $(6)$ & $(7)$ & $(8)$ \\
\hline \multirow[t]{2}{*}{$\begin{array}{l}\text { Sui Canal } \\
\text { Destroyed Section }\end{array}$} & $\begin{array}{l}-0.450 \\
(0.323)\end{array}$ & $\begin{array}{l}-0.042 \\
(0.279)\end{array}$ & $\begin{array}{l}1.108^{* *} \\
(0.445)\end{array}$ & $\begin{array}{c}0.824^{* * *} \\
(0.161)\end{array}$ & $\begin{array}{l}-0.358 \\
(0.418)\end{array}$ & $\begin{array}{l}-0.260 \\
(0.462)\end{array}$ & $\begin{array}{c}0.578^{* * *} \\
(0.203)\end{array}$ & $\begin{array}{c}0.800^{* * *} \\
(0.151)\end{array}$ \\
\hline & & & & & \multicolumn{4}{|c|}{ First Stage Regression: Sui Canal Destroyed Section } \\
\hline $\begin{array}{l}\text { Straight line } \\
\text { Destroyed Section }\end{array}$ & & & & & $\begin{array}{c}0.898^{* * *} \\
(0.088)\end{array}$ & $\begin{array}{c}0.898^{* * *} \\
(0.086)\end{array}$ & $\begin{array}{c}0.898^{* * *} \\
(0.086)\end{array}$ & $\begin{array}{c}0.900^{* * *} \\
(0.083)\end{array}$ \\
\hline Year of Census (LHS) & 2 & 140 & 742 & 1102 & 2 & 140 & 742 & 1102 \\
\hline Climate Controls & yes & yes & yes & yes & yes & yes & yes & yes \\
\hline Geography Controls & yes & yes & yes & yes & yes & yes & yes & yes \\
\hline $2 \times 2$ degree $\mathrm{FE}$ & yes & yes & yes & yes & yes & yes & yes & yes \\
\hline Kleibergen-Paap F-statistic & & & & & 102.1 & 109.6 & 109.6 & 117 \\
\hline Obs. & 1,254 & 1,254 & 1,254 & 1,254 & 1,254 & 1,254 & 1,254 & 1,254 \\
\hline \multicolumn{9}{|c|}{$\begin{array}{l}\text { Notes: }{ }^{*} p<0.10,{ }^{* *} p<0.05,{ }^{* *} p<0.01 \text {. Standard errors clustered at } 2 \times 2 \text { degree grid cells reported in parentheses. 'Year } \\
\text { of Census (LHS)' indicates the census to which the LHS variable corresponds. Climate controls include (log) precipitation } \\
\text { and (log) temperature. Geography controls include latitude, (log) distance to coast, (log) elevation, (log) ruggedness, (log) } \\
\text { area of grid cell, (log) agricultural suitability, and (log) rice suitability. Furthermore, the following geography-related dummy } \\
\text { variables are included: Coastline intersection, Yangtze River, Yangtze Delta, separate dummy variables for the intersection } \\
\text { with the past and contemporaneous course of the Yellow river, access to a river, and access to a lake. Regressions in al } \\
\text { columns with macroregion and } 2 \times 2 \text { degree grid-cell fixed effects. 'Kleibergen-Paap' represents the first-stage Kleibergen- } \\
\text { Paap F-statistic for the excluded instrument. }\end{array}$} \\
\hline
\end{tabular}

and construction of large-scale infrastructure projects that connected distant parts of the empire possible again. This suggests that there were no pre-existing infrastructure networks that influenced the path of Sui Canal. In Table B.1, we provide empirical support for this assertion by documenting that the extensive road network established during the Han dynasty which was maintained up until $220 \mathrm{CE}$ is uncorrelated with the course of the Sui Canal.

More generally, we take several steps to mitigate concern related to the possibility that unobservable factors bias our estimates. First, we include $2 \times 2$ degree grid cell fixed effects in all our regressions. This reduces the probability that unobservables influence our estimates as identifying variation is only generated by differences within the $2 \times 2$ degree grid cells. As shown in Table 2, conditional on these fixed effects, there are no statistically significant differences between grid cells that are intersected by the (instrumented) Sui Canal, and cells that are not. Second, we show that our results remain stable when we restrict the analysis to grid cells located within 75 kilometers of the Sui Canal (Table B.2. Third, we explicitly exploit the panel structure of the data (Table B.3). This allows us to account for time-invariant unobserved factors by including grid-cell level fixed effects. We further include the full set of climate and geographic control variables, each interacted 
with time-period indicator variables, to flexibly allow the effect of each factor to vary over time. As shown in Table B.3, the panel approach produces very similar results compared to the results presented in Table 3 above. While the panel approach helps address the (potential) issue of time-invariant unobserved factors, time-varying unobserved heterogeneity remains a concern. To gauge how strong the influence of unobservables would have to be to invalidate our findings, we employ the procedure developed in Oster (Forthcoming). We compare the point estimates obtained in a setup in which we only control for $2 \times 2$ grid cell fixed effects with the coefficients obtained when accounting for the full set of controls (i.e., geography and climate controls as well as $2 \times 2$ degree fixed effects). The results reported in Table B.4 indicate that the influence of unobservables would need to be 1.2 to 1.9 times more important than the included control variables to entirely attribute our results to the omission of unobserved factors 18 This increases confidence in our results.

We conduct a number of additional robustness checks to document the stability of our estimates. Specifically, we show that our results remain unchanged if account for potential spatial correlation (Tables B.5), define all grid cells as 'canal cells' if they lie within 11 kilometers of the canal (Table B.6), do not control for $2 \times 2$ grid cell fixed effects (Table B.7), or use an alternative standard error clustering approach (Table B.8). As a final exercise, we run a falsification test by shifting the Sui Canal lines in space (Table B.9). Reassuringly, this produces the expected null results. Taken together, the analysis presented above documents that the construction of the Sui Canal lead to a disproportionate increase in population along the course of the canal. Before investigating whether these effects persist into the current era, we discuss potential sources underlying this effect.

\section{Potential Channels Underlying Population Growth}

A direct channel through which the completion of the Sui Canal influenced population and economic growth is by reducing trade costs. Existing evidence indicates that waterborne transport was 9-10 times cheaper than overland transport in pre-industrial China (Shiue, 2002). It is well established, both theoretically and empirically, that a reduction in trade costs fosters economic growth (e.g., Storeygard (2016); Donaldson (Forthcoming)) 19 Further indication for the importance of transport costs in explaining our results are historical accounts of increased specialization in production along regions connected to the canal as well as the canal-induced emergence of an interregional commodity market (e.g., Xiong

\footnotetext{
${ }^{18}$ Both these values exceed 1 , the critical value recommended by Oster (Forthcoming).

${ }^{19}$ In a pre-industrial Malthusian era, economic growth is closely related to population growth.
} 
(2006, Chapter 4), Liu (2015, Chapter 4), Wu and Gaubatz (2012, p. 39)).

In addition to waterway-related reductions in transport costs, the construction of the canal could also have led to population growth via co-location of investment in alternative infrastructure. As outlined in Section 2, roads, granaries and post offices were built along the banks of the canal. This led to the establishment of settlements and market places (Berger, 1988, p.31). Additionally, population could have concentrated along the course of the canal due to increased labor demand related to the maintenance of the canal.

The discussion above outlines a number of channels through which the Sui Canal could have led to population growth. Due to the lack of data, we cannot asses the relative importance of these mechanisms. However, we can empirically address the question of whether the establishment of the trade network increased overall population numbers or simply led to a reorganization across space (e.g., Redding and Turner (2015)). Possible, for example, is that regions not directly connected to the canal lost population due to migration into nearby areas with access to the network. To investigate the extent of such spatial spillovers, positive or negative, we create three dummy variables in addition to the Sui Canal intersection indicator. These dummies capture whether a grid cell is 25-50, 50-75 or 75-100 kilometers away from the canal. We then include all four canal-related dummies in the regression setup (1) ${ }^{20}$ The results are presented in Table 5 . As before, there are no canal-related effects in census years prior to construction (columns (1)-(2)). In the years after completion, we observe statistically significantly higher population numbers in grid cells directly connected to the canal (columns (3)-(4), row 1). The sizes of the point estimates are very similar compared to the setup in which we only include the Sui Canal intersection dummy. However, there is no strong indication for the existence of spillover effects. We do not observe statistically significant effects when we move farther away from the canal. This suggests that the effects of the canal on population numbers were strong, but locally confined.

\subsection{Sui Canal, Modern-Day Population Concentration and Eco- nomic Activity}

Having established that the completion of the Sui Canal lead to an increase in population along its course during the period in which it was operational, we now investigate how

\footnotetext{
${ }^{20}$ We focus on the OLS approach since our IV procedure does not allow for a clean separation of the individual distance dummies.
} 
Table 5: Net Creation vs Reorganization

\begin{tabular}{lcccc}
\hline Dependent Variable & \multicolumn{4}{c}{ Total Population $(\mathrm{SD})_{t}$} \\
\cline { 2 - 5 } & $(1)$ & $(2)$ & $(3)$ & $(4)$ \\
\hline Sui Canal 0-25 km & -0.204 & -0.083 & $0.981^{* *}$ & $0.859^{* *}$ \\
& $(0.220)$ & $(0.217)$ & $(0.429)$ & $(0.413)$ \\
Sui Canal $25-50 \mathrm{~km}$ & -0.356 & -0.057 & 0.407 & -0.146 \\
& $(0.226)$ & $(0.143)$ & $(0.270)$ & $(0.171)$ \\
Sui Canal 50-75 km & -0.171 & -0.119 & 0.079 & -0.030 \\
& $(0.116)$ & $(0.096)$ & $(0.113)$ & $(0.099)$ \\
Sui Canal 75-100 km & -0.074 & -0.016 & 0.084 & 0.005 \\
& $(0.075)$ & $(0.084)$ & $(0.071)$ & $(0.077)$ \\
\hline Year of Census (LHS) & 2 & 140 & 742 & 1102 \\
Climate Controls & yes & yes & yes & yes \\
Geography Controls & yes & yes & yes & yes \\
$2 \times 2$ degree FE & yes & yes & yes & yes \\
\hline
\end{tabular}

Notes: ${ }^{*} p<0.10,{ }^{* *} p<0.05,{ }^{* * *} p<0.01$. Standard errors clustered at $2 \times 2$ degree grid cells reported in parentheses. 'Year of Census (LHS)' indicates the census to which the LHS variable corresponds. Climate controls include (log) precipitation and (log) temperature. Geography controls include latitude, (log) distance to coast, (log) elevation, (log) ruggedness, (log) area of grid cell, (log) agricultural suitability, and (log) rice suitability. Furthermore, the following geography-related dummy variables are included: Coastline intersection, Yangtze River, Yangtze Delta, separate dummy variables for the intersection with the past and contemporaneous course of the Yellow river, access to a river, and access to a lake. Regressions in all columns with macroregion and $2 \times 2$ degree grid-cell fixed effects.

persistent this effect is. We first analyze whether grid cells intersected by the section of the Sui Canal that fell into disrepair after the 12th century are still relatively densely populated. The results of Table 6 suggest that this is the case. The OLS point estimate in column (1) indicates that population in the year 2010 is 0.269 standard deviations higher in grid cells once connected to the Sui Canal. ${ }^{21}$ The straight-line instrumental variable approach produces a similar, although somewhat larger, point estimate (column (4)).22 The coefficient of 0.484 implies that previous access to the Sui Canal increases population by approximately 166,000 people. Compared to the historical era (columns (4) and (8) of Table 4), today's persistence-related canal effect is approximately 50 percent of its original magnitude. This indicates that the transport-access-driven shift in population concentration is extraordinarily persistent and only slowly dissipates over time. To further document the validity of these findings, we reproduce the results of columns (1) and (3) using night-time light intensity as an alternative proxy for population concentration in

\footnotetext{
${ }^{21}$ As mentioned above, we exclude all cells from our analysis that are intersected by the section of the Sui Canal that is still in use. Our results remain qualitatively unchanged if we use the full sample.

${ }^{22}$ The difference between the OLS and IV point estimate is statistically significant at the 95 percent confidence level.
} 
Table C.7 23

Table 6: Sui Canal and Population Concentration and Economic Activity 2010

\begin{tabular}{|c|c|c|c|c|c|c|}
\hline & \multicolumn{3}{|c|}{ OLS } & \multicolumn{3}{|c|}{ 2SLS-IV } \\
\hline & $\begin{array}{l}\text { Population (SD) } \\
\qquad(1)\end{array}$ & $\begin{array}{c}\text { GDP (SD) } \\
(2)\end{array}$ & $\begin{array}{c}\text { GDP per } \\
\text { capita (SD) } \\
(3)\end{array}$ & $\begin{array}{l}\text { Population (SD) } \\
\qquad(4)\end{array}$ & $\begin{array}{c}\text { GDP (SD) } \\
(5)\end{array}$ & $\begin{array}{c}\text { GDP per } \\
\text { capita }(\mathrm{SD}) \\
(6)\end{array}$ \\
\hline \multirow[t]{2}{*}{$\begin{array}{l}\text { Sui Canal } \\
\text { Destroyed Section }\end{array}$} & $\begin{array}{c}0.269^{* * *} \\
(0.057)\end{array}$ & $\begin{array}{l}-0.014 \\
(0.123)\end{array}$ & $\begin{array}{c}-0.076^{*} \\
(0.042)\end{array}$ & $\begin{array}{c}0.484^{* * *} \\
(0.087)\end{array}$ & $\begin{array}{c}0.004 \\
(0.175)\end{array}$ & $\begin{array}{c}-0.144^{* * *} \\
(0.050)\end{array}$ \\
\hline & & & & \multicolumn{3}{|c|}{ First Stage Regression: Sui Canal Destroyed Section } \\
\hline $\begin{array}{l}\text { Straight line } \\
\text { Destroyed Section }\end{array}$ & & & & $\begin{array}{c}0.900^{* * *} \\
(0.081)\end{array}$ & $\begin{array}{c}0.900^{* * *} \\
(0.081)\end{array}$ & $\begin{array}{c}0.900^{* * *} \\
(0.081)\end{array}$ \\
\hline Climate Controls & yes & yes & yes & yes & yes & yes \\
\hline Geography Controls & yes & yes & yes & yes & yes & yes \\
\hline $2 \times 2$ degree $\mathrm{FE}$ & yes & yes & yes & yes & yes & yes \\
\hline Kleibergen-Paap & & & & 124.2 & 124.2 & 124.2 \\
\hline Obs. & 1,254 & 1,254 & 1,254 & 1,254 & 1,254 & 1,254 \\
\hline
\end{tabular}

Notes: ${ }^{*} p<0.10,{ }^{* *} p<0.05,{ }^{* * *} p<0.01$. Standard errors clustered at $2 \times 2$ degree grid cells reported in parentheses. Climate controls include (log) precipitation and (log) temperature. Geography controls include latitude, (log) distance to coast, (log) elevation, (log) ruggedness, (log) area of grid cell, (log) agricultural suitability, and (log) rice suitability. Furthermore, the following geography-related dummy variables are included: Coastline intersection, Yangtze River, Yangtze Delta, separate dummy variables for the intersection with the past and contemporaneous course of the Yellow river, access to a river, and access to a lake. Regressions in all columns with macroregion and $2 \times 2$ degree grid-cell fixed effects. 'KleibergenPaap' represents the first-stage Kleibergen-Paap F-statistic for the excluded instrument.

An immediate question is whether the population concentration along the former course of the canal is reflected in a similar concentration of economic activity. As depicted in columns (2) and (5), this is not the case. Total GDP in grid cells once connected to the Sui Canal is not significantly higher than in other areas. Combined with the persistence-related higher population, this suggest that GDP per capita is lower in grid cells along the defunct sections of the transport network. The results presented in columns (3) and (6) support this notion. The IV point estimate, for example, implies that having been connected to the Sui Canal reduces current-day GDP per capita by economically meaningful 0.14 standard deviations (column (6)).

In the final step of our analysis, we discuss potential mechanisms underlying the observed persistence in the spatial distribution of population as well as the GDP effects. Note that all results in Table 6 remain stable when we subject them to the same robustness test as in Section 5.1 (see Appendix C). Also recall that grid cells connected to the defunct part of the canal are not different in terms of observables (Table 2), supporting the view that

\footnotetext{
${ }^{23}$ As documented in Henderson et al. (2018a, p.371), within-country variation in night-time light intensity primarily reflects variation in population density and to a much lesser extent income per capita. This is particularly true in the case of China as the electrification rate is almost 100 percent (World Bank Developing Indicators 2010) and therefore likely conveys little information regarding income.
} 
our estimates are in fact capturing persistence-related effects ${ }^{24}$ Table C.6 further shows that the influence of unobservables would have to be substantial in order to attribute our findings to omitted variables. Placebo tests presented in Table C.8 again yield the expected null results.

Potential Channels Underlying Persistence in Population Concentration and Negative GDP Effect

The literature on economic geography has proposed several mechanisms to explain why the spatial distribution of population remains stable over time. Often a concentration of population is observed in areas that exhibit advantages in terms of productivity or access to markets (e.g., Henderson et al. (2018b)). In the context of our study, the construction of the Sui Canal represents an event that reduces transport costs, increases productivity, and leads to a local increase in population concentration (Table 4). This surge in population numbers also leads to an increase in market size and integration around the canal, which can persist even if the original advantage - i.e., the Sui Canal - that triggered the increase in population ceases to exist. Persistence of population concentration, i.e., market size, is particularly likely in the presence of increasing returns in production (e.g., Krugman, 1999). Combined with the fact that China was a closed economy during most of its history, this implies that being located along the former course of the Sui Canal in the center of the country did not represent a disadvantage in terms of transport costs and market access. Economic incentives for individual to move away from these regions were therefore likely small in the era of limited international trade.25

The existence of other types of increasing returns to scale could further explain the observed persistence in the spatial distribution of population. For example, as a result of sunk investments or local information spillovers - or more generally Marshallian externalities (Venables, 2008) - population will remain concentrated in regions even if the advantage that led to the concentration in the first place has ceased to exist (e.g., Bleakley and Lin (2012); Jedwab et al. (2017)).

\footnotetext{
${ }^{24}$ If we restrict our attention to grid cells that lay along the Sui canal and compare grids that were integrated into the Grand Canal with grids that were connected to the part of the Sui Canal that fell into disrepair, we do not observe any differences in observables (results available from the authors upon request). This provides further evidence that locational fundamentals did not influence which part of the canal was rebuilt and mitigate concerns related to selection.

${ }^{25}$ While we lack access to spatially highly disaggregated data to formally establish the (continued) stability over time, the results of Flückiger and Ludwig (2017) indicate that the spatial distribution of population was very stable during the Imperial Era.
} 
Typically the mechanisms generating persistence in the spatial distribution of population (e.g., market access or increasing returns to scale) also imply higher productivity - and therefore GDP per capita - in densely populated areas. While income in regions connected to the Sui Canal indeed seems to have been higher in historical times (e.g., Liu (2015, Chapter 4)) this is no longer the case today (Table 6, columns (3) and (6)). Sui Canal-related population concentration is associated with lower GDP per capita. Typical persistence-generating mechanisms developed in the economic geography literature can therefore not consolidate our findings for the current era. Reliance on local networks, preventing migration, could be one explanation why we observe people to be concentrated in low income areas. For India, for example, Munshi and Rosenzweig (2016) document that the reliance on informal rural insurance networks (due to the absence of a formal insurance market) dissuades migration to urban regions, despite the existence of a significant rural-urban income gap. A similar mechanism could be at play in China. Hong et al. (2006), for example, show that migrant workers in China generally do not have access to formal health insurance. Additionally, the existence of substantial mobility restrictions, the 'Hukou' system, within China could be an important factor explaining our results. The migration-deterring mechanisms outlined above imply the misallocation of labor across space (Munshi and Rosenzweig, 2016). People would be better off if they migrated out of the regions that were once connected to the Sui Canal. Based on the data available to us, it is not possible to identify the dominant mechanisms that explain the observed persistence in population concentration around the Sui Canal. However, conditional on population being very inert, the switch to an export-led industrialization regime is potentially an important factor explaining the negative effect on GDP per capita. Since the start of the Open Door Policy in 1979, state-led (industrial) investments, domestic as well as foreign, have been concentrated in coastal regions due to preferential policy treatment, as well as the regions' advantageous location which provides direct access to the world markets (e.g., Démurger et al. (2002); Lemoine et al. (2015)). Under the new policy regime, locations in the center of the country are disadvantaged in terms of public investments as well as transport costs. Given the persistence in the spatial distribution of population documented in Table 6 this can lead to a (temporary) lock-in effect, where the 'trapped' population is relatively less well off in income per capita terms. Table 7 below provides suggestive evidence that public expenditure, proxied by the density of highways, railway lines as well as airports, is not proportional to population numbers in regions previously intersected by 
the Sui Canal 26 For all proxies, the OLS as well as IV point estimates are statistically non-significant. Combined with a higher population density, this implies that investments per capita is lower which could contribute to our findings.

Table 7: Sui Canal and Infrastructure 2010

\begin{tabular}{|c|c|c|c|c|c|c|}
\hline & \multicolumn{3}{|c|}{ OLS } & \multicolumn{3}{|c|}{ 2SLS-IV } \\
\hline & $\begin{array}{c}\text { Total Length } \\
\text { Highways (SD) } \\
\text { (1) }\end{array}$ & $\begin{array}{c}\text { Total Length } \\
\text { Railway Lines (SD) } \\
(2)\end{array}$ & $\begin{array}{c}\text { Number of } \\
\text { Airports (SD) } \\
(3)\end{array}$ & $\begin{array}{c}\text { Total Length } \\
\text { Highways (SD) } \\
\text { (4) }\end{array}$ & $\begin{array}{c}\text { Total Length } \\
\text { Railway Lines (SD) } \\
(5)\end{array}$ & $\begin{array}{c}\text { Number of } \\
\text { Airports (SD) } \\
(6)\end{array}$ \\
\hline \multirow[t]{2}{*}{$\begin{array}{l}\text { Sui Canal } \\
\text { Destroyed Section }\end{array}$} & $\begin{array}{l}-0.073 \\
(0.166)\end{array}$ & $\begin{array}{c}0.216 \\
(0.220)\end{array}$ & $\begin{array}{c}0.044 \\
(0.038)\end{array}$ & $\begin{array}{l}-0.217 \\
(0.254)\end{array}$ & $\begin{array}{l}-0.066 \\
(0.196)\end{array}$ & $\begin{array}{r}0.043 \\
(0.035)\end{array}$ \\
\hline & & & & \multicolumn{3}{|c|}{ First Stage Regression: Sui Canal Destroyed Section } \\
\hline $\begin{array}{l}\text { Straight line } \\
\text { Destroyed Section }\end{array}$ & & & & $\begin{array}{c}0.900^{* * *} \\
(0.081)\end{array}$ & $\begin{array}{c}0.900^{* * *} \\
(0.081)\end{array}$ & $\begin{array}{c}0.900^{* * *} \\
(0.081)\end{array}$ \\
\hline Climate Controls & yes & yes & yes & yes & yes & yes \\
\hline Geography Controls & yes & yes & yes & yes & yes & yes \\
\hline $2 \times 2$ degree $\mathrm{FE}$ & yes & yes & yes & yes & yes & yes \\
\hline Kleibergen-Paap & & & & 124.2 & 124.2 & 124.2 \\
\hline Obs. & 1,254 & 1,254 & 1,254 & 1,254 & 1,254 & 1,254 \\
\hline
\end{tabular}

Notes: ${ }^{*} p<0.10,{ }^{* *} p<0.05,{ }^{* * *} p<0.01$. Standard errors clustered at $2 \times 2$ degree grid cells reported in parentheses. Climate controls include (log) precipitation and (log) temperature. Geography controls include latitude, (log) distance to coast, (log) elevation, (log) ruggedness, (log) area of grid cell, (log) agricultural suitability, and (log) rice suitability. Furthermore, the following geography-related dummy variables are included: Coastline intersection, Yangtze River, Yangtze Delta, separate dummy variables for the intersection with the past and contemporaneous course of the Yellow river, access to a river, and access to a lake. Regressions in all columns with macroregion and $2 \times 2$ degree grid-cell fixed effects. 'KleibergenPaap' represents the first-stage Kleibergen-Paap F-statistic for the excluded instrument.

All data extracted from http://worldmap.harvard.edu.

\section{Conclusion}

This paper shows that transport infrastructure projects have the capacity to change the spatial pattern of population concentration over the very long run. The influence of the transport network on the spatial distribution of population can persist long after the network has ceased to be operational. Our results further suggest that when the value of locational fundamentals changes over time and population adapts only slowly, this can result in a negative per capita GDP effect in areas that are highly populous owing to their previous locational advantages.

${ }^{26}$ Transport infrastructure investments is a commonly used as a proxy for public investment (e.g., Jedwab et al. (2017)). In China, investments in infrastructure make up $24 \%$ of total fixed asset investment (Financial Times, 24 August 2017). 


\section{References}

Banerjee, Abhijit, Esther Duflo, and Nancy Qian (2012) 'On the road: Access to transportation infrastructure and economic growth in China.' Working Paper 17897, National Bureau of Economic Research, March

Baum-Snow, Nathaniel, Loren Brandt, J. Vernon Henderson, Matthew A. Turner, and Qinghua Zhang (2017) 'Roads, railroads, and decentralization of Chinese cities.' The Review of Economics and Statistics 99(3), 435-448

Berger, Friedemann (1988) Die Milchstrasse am Himmel und der Kanal auf Erden (Beijing: Verlag für fremdsprachige Literatur)

Bielenstein, Hans (1987) Chinese Historical Demography A.D. 2-1982 Bulletin No. 59 (Stockholm: The Museum of Far Eastern Antiquities)

Bleakley, Hoyt, and Jeffrey Lin (2012) 'Portage and path dependence.' The Quarterly Journal of Economics 127(2), 587-644

Bosker, Maarten, Steven Brakman, Harry Garretsen, and Marc Schramm (2007) 'Looking for multiple equilibria when geography matters: German city growth and the WWII shock.' Journal of Urban Economics 61(1), 152 - 169

Chi, Ch'ao-Ting (1970) Key Economic Areas in Chinese History (New York: August M. Kelley)

Conley, T. G. (1999) 'GMM estimation with cross sectional dependence.' Journal of Econometrics 92(1), 1-45

Davis, Donald R., and David E. Weinstein (2002) 'Bones, bombs, and break points: The geography of economic activity.' American Economic Review 92(5), 1269-1289

Dell, Melissa (2010) 'The Persistent Effects of Peru's Mining Mita.' Econometrica $78(6), 1863-1903$

Démurger, Sylvie, Jeffrey D. Sachs, Wing Thye Woo, Shuming Bao, and Gene Chang (2002) 'The relative contributions of location and preferential policies in China's regional development: Being in the right place and having the right incentives.' China Economic Review 13(4), $444-465$

Desmet, Klaus, Dávid Krisztián Nagy, and Esteban Rossi-Hansberg (Forthcoming) 'The geography of development.' Journal of Political Economy

Dincecco, Mark, and Massimiliano Gaetano Onorato (2016) 'Military conflict and the rise of urban Europe.' Journal of Economic Growth 21(3), 259-282 
Donaldson, Dave (Forthcoming) 'Railroads of the Raj: Estimating the impact of transportation infrastructure.' American Economic Review

Donaldson, Dave, and Richard Hornbeck (2016) 'Railroads and American economic growth: A market access approach.' Quarterly Journal of Economics 131(2), 799-858

Ebrey, Patricia Buckley (1996) The Cambridge Illustrated History of China Cambridge Illustrated Histories (Cambridge University Press)

Faber, Benjamin (2014) 'Trade integration, market size, and industrialization: Evidence from China's national trunk highway system.' The Review of Economic Studies 81(3), 1046-1070

Flückiger, Matthias, and Markus Ludwig (2017) 'Malaria suitability, urbanization and persistence: Evidence from China over more than 2000 years.' European Economic Review 92(C), 146-160

Galor, Oded, and Ömer Özak (2015) 'Land productivity and economic development: Caloric suitability vs. agricultural suitability.' Technical Report

Gaughan, Andrea E., Forrest R. Stevens, Zhuojie Huang, Jeremiah J. Nieves, Alessandro Sorichetta, Shengjie Lai, Xinyue Ye, Catherine Linard, Graeme M. Hornby, Simon I. Hay, Hongjie Yu, and Andrew J. Tatem (2016) 'Spatiotemporal patterns of population in mainland China, 1990 to 2010.' Scientific Data

Henderson, J. Vernon, Tim L. Squires, Adam Storeygard, and David N. Weil (2018a) 'The global spatial distribution of economic activity: Nature, history, and the role of trade.' Quarterly Journal of Economics 133, 357-406

Henderson, J Vernon, Tim Squires, Adam Storeygard, and David Weil (2018b) 'The global distribution of economic activity: Nature, history, and the role of trade1.' The Quarterly Journal of Economics 133(1), 357-406

Henderson, J. Vernon, Zmarak Shalizi, and Anthony J. Venables (2001) 'Geography and development.' Journal of Economic Geography 1(1), 81-105

Hijmans, Robert J., Susan E. Cameron, Juan L. Parra, Peter G. Jones, and Andy Jarvis (2005) 'Very high resolution interpolated climate surfaces for global land areas.' International Journal of Climatology 25(15), 1965-1978

Hong, Yan, Xiaoming Li, Bonita Stanton, Danhua Lin, Xiaoyi Fang, Mao Rong, and Jing Wang (2006) 'Too costly to be ill: Health care access and health seeking behaviors among rural-to-urban migrants in china.' World health $\mathscr{E}$ population 8(2), 22-34 
Hornung, Erik (2015) 'Railroads and growth in Prussia.' Journal of the European Economic Association 13(4), 699-736

Huang, Yaohuan, Dong Jiang, and Jingying Fu (2014) '1 km grid GDP data of China (2005, 2010).' Acta Geographica Sinica

IIASA/FAO (2012) Global Agro-ecological Zones (GAEZ v3.0) International Institute for Applied Systems Analysis and Food and Agriculture Organization of the United Nations (Laxenburg, Austria and Rome, Italy)

Iyigun, Murat, Nathan Nunn, and Nancy Qian (2017) 'The long-run effects of agricultural productivity on conflict, 1400-1900.' Working Paper 24066, National Bureau of Economic Research, November

Jedwab, Remi, and Alexander Moradi (2016) 'The permanent effects of transportation revolutions in poor countries: Evidence from Africa.' The Review of Economics and Statistics 98(2), 268-284

Jedwab, Remi, Edward Kerby, and Alexander Moradi (2017) 'History, path dependence and development: Evidence from colonial railroads, settlers and cities in Kenya.' Economic Journal 127(603), 1467-1494

Krugman, Paul (1999) 'The role of geography in development.' International Regional Science Review 22(2), 142-161

Lemoine, Françoise, Sandra Poncet, and Deniz Ünal (2015) 'Spatial rebalancing and industrial convergence in China.' China Economic Review 34(C), 39-63

Liu, William Guanglin (2015) The Chinese Market Economy (Albany, NY: State University of New York Press)

Marks, Robert B. (2011) China: Its Environment and History (Rowman \& Littlefield Publishers)

Michaels, Guy, and Ferdinand Rauch (2013) 'Resetting the Urban Network: 117-2012.' CEPR Discussion Papers 9760, C.E.P.R. Discussion Papers, November

Michalopoulos, Stelios, and Elias Papaioannou (2013) 'Pre-colonial ethnic institutions and contemporary African development.' Econometrica 81(1), 113-152

Miguel, Edward, and Gerard Roland (2011) 'The long-run impact of bombing Vietnam.' Journal of Development Economics 96(1), 1 - 15

Motamed, Mesbah J., Raymond J.G.M. Florax, and William A. Masters (2014) 'Agriculture, transportation and the timing of urbanization: Global analysis at the grid cell 
level.' Journal of Economic Growth 19(3), 339-368

Munshi, Kaivan, and Mark Rosenzweig (2016) 'Networks and misallocation: Insurance, migration, and the rural-urban wage gap.' American Economic Review 106(1), 46-98

Needham, Joseph, Lu Gwei-Djen, and Ling Wang (1971) Science and Civilisation in China, vol. 4 of Science and Civilisation in China (Cambridge University Press)

Nunn, Nathan (2008) 'The Long-term Effects of Africa's Slave Trades.' The Quarterly Journal of Economics 123(1), 139-176

Nunn, Nathan, and Diego Puga (2012) 'Ruggedness: The blessing of bad geography in Africa.' The Review of Economics and Statistics 94(1), 20-36

Nunn, Nathan, and Nancy Qian (2011) 'The Potato's Contribution to Population and Urbanization: Evidence From A Historical Experiment.' The Quarterly Journal of Economics 126(2), 593-650

Oster, Emily (Forthcoming) 'Unobservable selection and coefficient stability: Theory and evidence.' Journal of Business \& Economic Statistics

Rappaport, Jordan, and Jeffrey D. Sachs (2003) 'The United States as a coastal nation.' Journal of Economic Growth 8(1), 5-46

Redding, Stephen J., and Matthew A. Turner (2015) Transportation Costs and the Spatial Organization of Economic Activity, vol. 5 of Handbook of Regional and Urban Economics,

Redding, Stephen J., Daniel M. Sturm, and Nikolaus Wolf (2010) 'History and industry location: Evidence from German airports.' Review of Economics and Statistics 93(3), 814831

Shiue, Carol H. (2002) 'Transport costs and the geography of arbitrage in eighteenthcentury china.' American Economic Review 92(5), 1406-1419

Skinner, G. William (1977) 'Regional urbanization in nineteenth-century China.' In Studies in Chinese Society, ed. G. William Skinner (Stanford, California: Stanford University Press) pp. 211-252

Storeygard, Adam (2016) 'Farther on down the road: Transport costs, trade and urban growth in sub-saharan africa.' The Review of Economic Studies 83(3), 1263-1295

Venables, Anthony J. (2008) 'Economic geography.' In The Oxford Handbook of Political Economy, ed. Donald A. Wittman and Barry R. Weingast (Oxford University Press)

Wright, Arthur F. (1979) 'The Sui dynasty (581-617).' In The Cambridge History of China: Volume 3, Sui and T'ang China, 589-906 AD, Part One, ed. Denis Twitchett and John K. 
Fairbank The Cambridge History of China (Cambridge University Press) chapter 2, pp. $48-149$

Wu, Weiping, and Piper Rae Gaubatz (2012) The Chinese City (Routledge)

Xiong, Victor Cunrui (2006) Emperor Yang of the Sui Dynasty: His Life, Times, and Legacy SUNY series in Chinese Philosophy and Culture (State University of New York Press)

Zhang, Xiaobo, and Shenggen Fan (2004) 'Public investment and regional inequality in rural china.' Agricultural Economics 30(2), 89-100 


\section{Appendices}

\section{A Instrumental Variable Approach Visualized}

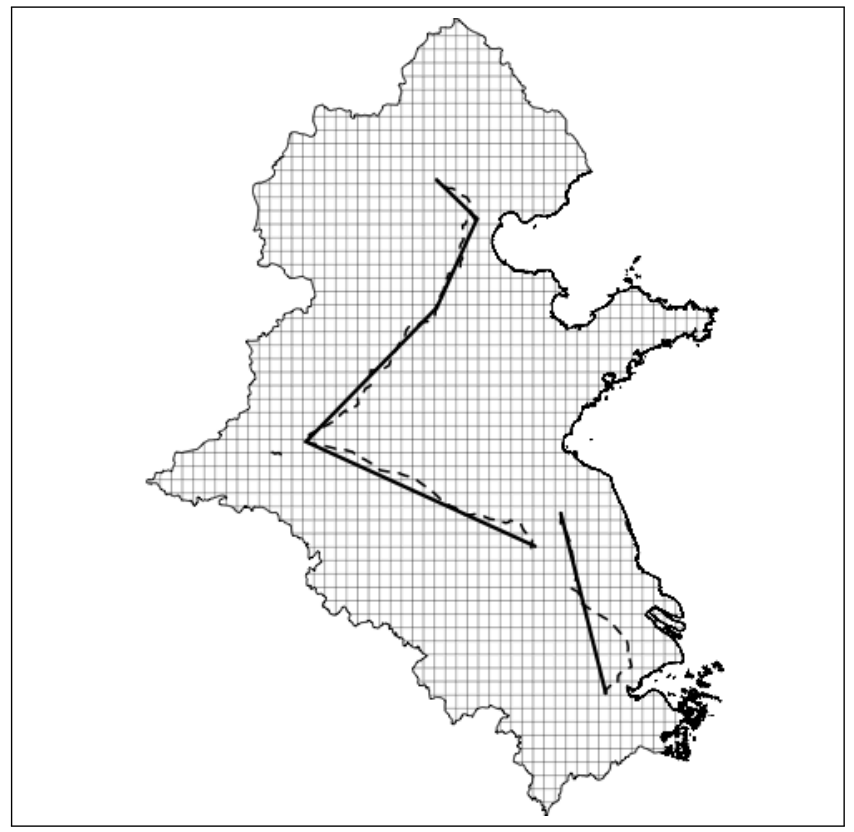

Figure A.1: Figure depicts Sui Canal as well as straight-line corridors connecting nodes. 


\title{
B Robustnessand Falsification Checks Historical Era
}

\author{
Han Road Network and Sui Canal
}

Table B.1: Han Road Network and Sui Canal

\begin{tabular}{lccccc}
\hline Dependent Variable & \multicolumn{2}{c}{ Presence Network } & & \multicolumn{2}{c}{ Length Han Network } \\
\cline { 2 - 3 } \cline { 5 - 6 } & $(1)$ & $(2)$ & & $(3)$ & $(4)$ \\
\hline Sui Canal & 0.023 & & & 0.125 & \\
& $(0.071)$ & & & $(0.221)$ & \\
Sui Canal & & -0.029 & & 0.026 \\
Destroyed Section & & $(0.081)$ & & $(0.287)$ \\
\hline Year of Census (LHS) & 742 & 742 & & 742 & 742 \\
Climate Controls & yes & yes & yes & yes \\
Geography Controls & yes & yes & yes & yes \\
R-squared & 0.112 & 0.112 & & 0.107 & 0.107 \\
Obs. & 1,374 & 1,374 & & 1,374 & 1,374 \\
\hline
\end{tabular}

Notes: ${ }^{*} p<0.10,{ }^{* *} p<0.05,{ }^{* * *} p<0.01$. Regressions in all columns with macroregion and climate-zone dummies. Standard errors clustered at $2 \times 2$ degree grid cells reported in parentheses. 'Presence Network' represents a dummy variable indicating whether a grid cell was intersected by the road network or not. 'Length Han Network' is the (log) length of the network. 'Year of Census (LHS)' indicates the census to which the LHS variable corresponds. Climate controls include $(\log )$ precipitation and $(\log )$ temperature. Geography controls include latitude, (log) distance to coast, (log) elevation, (log) ruggedness, (log) area of grid cell, and (log) agricultural suitability. Furthermore, the following geography-related dummy variables are included: Coastline intersection, Yangtze River, Yangtze Delta, separate dummy variables for the intersection with the past and contemporaneous course of the Yellow river, access to a river, and access to a lake. 


\section{Restricting Sample to Grid Cells Within 75 Kilometers of Sui Canal}

Table B.2: Sui Canal and Population Concentration in Historical Era: Cells within 75 kilometers of Sui Canal

\begin{tabular}{|c|c|c|c|c|c|c|c|c|}
\hline \multirow[t]{3}{*}{ Dependent Variable } & \multicolumn{8}{|c|}{ Total Population $(\mathrm{SD})_{t}$} \\
\hline & \multicolumn{4}{|c|}{ OLS } & \multicolumn{4}{|c|}{ 2SLS-IV } \\
\hline & (1) & $(2)$ & $(3)$ & (4) & $(5)$ & (6) & (7) & (8) \\
\hline \multirow[t]{2}{*}{ Sui Canal } & $\begin{array}{c}-0.079 \\
(0.165)\end{array}$ & $\begin{array}{l}-0.035 \\
(0.125)\end{array}$ & $\begin{array}{c}0.606^{* *} \\
(0.209)\end{array}$ & $\begin{array}{c}0.860 * * * \\
(0.265)\end{array}$ & $\begin{array}{c}0.029 \\
(0.340)\end{array}$ & $\begin{array}{l}-0.109 \\
(0.233)\end{array}$ & $\begin{array}{c}0.665^{* * *} \\
(0.201)\end{array}$ & $\begin{array}{c}0.762^{* * *} \\
(0.153)\end{array}$ \\
\hline & & & & & \multicolumn{4}{|c|}{ First Stage Regression: Sui Canal } \\
\hline Straight line & & & & & $\begin{array}{c}0.596^{* * *} \\
(0.149) \\
\end{array}$ & $\begin{array}{c}0.606^{* * *} \\
(0.154) \\
\end{array}$ & $\begin{array}{c}0.606^{* * *} \\
(0.154) \\
\end{array}$ & $\begin{array}{c}0.613^{* * *} \\
(0.159) \\
\end{array}$ \\
\hline Year of Census (LHS) & 2 & 140 & 742 & 1102 & 2 & 140 & 742 & 1102 \\
\hline Climate Controls & yes & yes & yes & yes & yes & yes & yes & yes \\
\hline Geography Controls & yes & yes & yes & yes & yes & yes & yes & yes \\
\hline $2 \times 2$ degree $\mathrm{FE}$ & yes & yes & yes & yes & yes & yes & yes & yes \\
\hline Kleibergen-Paap F-statistic & & & & & 15.96 & 15.38 & 15.38 & 14.92 \\
\hline Obs. & 262 & 262 & 262 & 262 & 262 & 262 & 262 & 262 \\
\hline
\end{tabular}

Notes: ${ }^{*} p<0.10,{ }^{* *} p<0.05,{ }^{* * *} p<0.01$. Standard errors clustered at $2 \times 2$ degree grid cells reported in parentheses. 'Year of Census (LHS)' indicates the census to which the LHS variable corresponds. Climate controls include (log) precipitation and $(\log )$ temperature. Geography controls include latitude, (log) distance to coast, (log) elevation, (log) ruggedness, (log) area of grid cell, $(\log )$ agricultural suitability, and $(\log )$ rice suitability. Furthermore, the following geography-related dummy variables are included: Coastline intersection, Yangtze River, Yangtze Delta, separate dummy variables for the intersection with the past and contemporaneous course of the Yellow river, access to a river, and access to a lake. Regressions in all columns with macroregion and $2 \times 2$ degree grid-cell fixed effects. 'Kleibergen-Paap' represents the first-stage KleibergenPaap F-statistic for the excluded instrument. 


\section{Panel Data Analysis}

We exploit the panel data structure of the historical population data (i.e., for the years 2, 140, 742 and 1102) to show that time-invariant unobservable factors do not bias our cross-sectional OLS estimates presented in Section 5. Specifically, we run regressions of the following form:

$$
p_{c, t}=\gamma \text { Sui Canal Completed } c_{c, t}+\theta_{t}+\mu_{c}+\beta^{\prime} s \mathbf{X} \varepsilon_{c, t} .
$$

As before, $p_{c, t}$ represents (standardized) total population of grid cell $c$ in year $t$. 'Sui Canal Completed $_{c, t}$ ' is a variable that takes the value one if a grid cell is intersected by the Sui Canal after its completion (that is, in the years 742 and 1102). Time dummies $\left(\theta_{t}\right)$ as well as grid cell fixed effects $\left(\mu_{c}\right)$ are also included. The inclusion of the latter implies that we will only rely on within-cell changes in access to the Sui Canal for identification. Any timeinvariant between-cell differences will be absorbed by the cell-specific fixed effects. The idiosyncratic error term is symbolized by $\varepsilon_{c, t}$. In analogy to the cross-sectional regressions, we include the geographic and climatic control variables, where each factor is interacted with the full set of time-period indicator variables. This allows the effect of each factor to vary flexibly over time.

In order to allow the Sui-Canal effect to vary flexibly over the years, we also estimate a regression setup in which we replace the variable 'Sui Canal Completed C.t $^{\prime}$ ' by the interaction

of the (time-invariant) Sui Canal indicator with each of the time-period fixed effects. That is, we estimate the effect of the Sui Canal, relative to the baseline time-period $2 \mathrm{CE}$, separately for the year 140, 742 and 1102

Table B.3 depicts the results of our panel data regressions. Column (1) shows that cells that gained direct access to the Sui Canal after its completion in the 7th century experienced a disproportionate increase in population compared to the rest of the grid cells. Column (2) shows that this effect is observable in both post-construction time periods (i.e,. 742 and 1102) but not for the year 140. Compared to the point estimates of Table 3 (columns (2)(4)) the coefficients obtained in the panel-data approach are very similar. This indicates that unobserved, time-invariant heterogeneity does not bias our cross-section regression results presented in the main part. 
Table B.3: Sui Canal and Population Concentration in Historical Era: Panel Data Regressions

\begin{tabular}{lcc}
\hline \multicolumn{1}{c}{ Dependent Variable } & \multicolumn{2}{c}{ Total Population $(\mathrm{SD})_{t}$} \\
\cline { 2 - 3 } & $(1)$ & $(2)$ \\
\hline Sui Canal & $1.082^{* * *}$ & \\
$\quad$ Completed & $(0.199)$ & \\
Sui Canal 140 & & -0.014 \\
& & $(0.111)$ \\
Sui Canal 742 & & $0.743^{* * *}$ \\
& & $(0.168)$ \\
Sui Canal 1102 & & $1.406^{* * *}$ \\
& & $(0.321)$ \\
\hline Control variable time-indicator interactions & yes & yes \\
Year fixed effects & yes & yes \\
Grid fell fixed effects & yes & yes \\
Obs. & 5,124 & 5,124 \\
\hline
\end{tabular}

Notes: ${ }^{*} p<0.10$,** $^{*}<0.05,{ }^{* * *} p<0.01$. Regressions in all columns with grid cell fixed effects and full set of time-interacted control variables. Standard errors clustered at the individual grid cell reported in parentheses. 'Sui Canal Completed' is a variable that takes the value one if a grid cell is intersected by the Sui Canal after its completion (that is, in the years 742 and 1102). 'Sui Canal 140' represents the interaction between a dummy for the year 140 and the intersection with the Sui Canal; 'Sui Canal 742' represents the interaction between a dummy for the year 742 and the intersection with the Sui Canal; 'Sui Canal 1102' represents the interaction between a dummy for the year 1102 and the intersection with the Sui Canal. 


\section{Gauging Influence of Omitted Variables}

Table B.4: Oster (Forthcoming $)$ Approach to Gauge Influence of Omitted Variables

\begin{tabular}{lcccc}
\hline Dependent Variable & $\delta$ & $R^{2}$ & $R^{2}$ & $R_{\text {max }}^{2}$ \\
& & no controls & full set of controls & \\
\hline Population 742 (SD) & 1.592 & 0.095 & 0.554 & 0.721 \\
Population 1102 (SD) & 3.267 & 0.053 & 0.404 & 0.525 \\
\hline
\end{tabular}

Notes: The parameter $\delta$ represents how strong the influence of unobservables relative to observables would have to be in order to suppress the Sui Canal effect. $R^{2} 2 \times 2 F E$ captures the explanatory power obtained from regressions in which we only control for $2 \times 2$ grid cell fixed effects. $R^{2}$ full set of controls reflects the explanatory power obtained from the regressions that control for full set of controls. Following the recommendation of Oster (Forthcoming), we assume that the maximum achievable R-squared exceeds the R-squared obtained when including all observable covariates by $30 \%$. Negative values of $\delta$ indicate that the estimates are, if anything, biased downwards. 


\section{Adding Fourth-Order Longitude/Latitude Polynomial}

Table B.5: Sui Canal and Population Concentration in Historical Era: Longitude/Latitude Polynomial

\begin{tabular}{|c|c|c|c|c|c|c|c|c|}
\hline \multirow[t]{3}{*}{ Dependent Variable } & \multicolumn{8}{|c|}{ Total Population $(\mathrm{SD})_{t}$} \\
\hline & \multicolumn{4}{|c|}{ OLS } & \multicolumn{4}{|c|}{ 2SLS-IV } \\
\hline & (1) & (2) & (3) & $(4)$ & $(5)$ & $(6)$ & $(7)$ & $(8)$ \\
\hline \multirow[t]{2}{*}{ Sui Canal } & $\begin{array}{c}-0.027 \\
(0.184)\end{array}$ & $\begin{array}{c}-0.026 \\
(0.146)\end{array}$ & $\begin{array}{c}0.793^{* *} \\
(0.304)\end{array}$ & $\begin{array}{c}0.928^{* * *} \\
(0.341)\end{array}$ & $\begin{array}{c}-0.045 \\
(0.390)\end{array}$ & $\begin{array}{c}-0.272 \\
(0.187)\end{array}$ & $\begin{array}{c}0.699 * * * \\
(0.256)\end{array}$ & $\begin{array}{c}0.635^{* * *} \\
(0.178)\end{array}$ \\
\hline & & & & & \multicolumn{4}{|c|}{ First Stage Regression: Sui Canal } \\
\hline Straight line & & & & & $\begin{array}{c}0.599^{* * *} \\
(0.166)\end{array}$ & $\begin{array}{c}0.604^{* * *} \\
(0.168)\end{array}$ & $\begin{array}{c}0.604^{* * *} \\
(0.168)\end{array}$ & $\begin{array}{c}0.609 * * * \\
(0.170)\end{array}$ \\
\hline 4th order lon/lat polynomial & yes & yes & yes & yes & yes & yes & yes & yes \\
\hline Year of Census (LHS) & 2 & 140 & 742 & 1102 & 2 & 140 & 742 & 1102 \\
\hline Climate Controls & yes & yes & yes & yes & yes & yes & yes & yes \\
\hline Geography Controls & yes & yes & yes & yes & yes & yes & yes & yes \\
\hline $2 \times 2$ degree $\mathrm{FE}$ & yes & yes & yes & yes & yes & yes & yes & yes \\
\hline Kleibergen-Paap F-statistic & & & & & 13.01 & 12.96 & 12.96 & 12.90 \\
\hline Obs. & 1,281 & 1,281 & 1,281 & 1,281 & 1,281 & 1,281 & 1,281 & 1,281 \\
\hline
\end{tabular}

Notes: ${ }^{*} p<0.10,{ }^{* *} p<0.05,{ }^{* * *} p<0.01$. Standard errors clustered at $2 \times 2$ degree grid cells reported in parentheses. 'Year of Census (LHS)' indicates the census to which the LHS variable corresponds. Climate controls include (log) precipitation and $(\log )$ temperature. Geography controls include latitude, (log) distance to coast, (log) elevation, (log) ruggedness, (log) area of grid cell, (log) agricultural suitability, and (log) rice suitability. Furthermore, the following geography-related dummy variables are included: Coastline intersection, Yangtze River, Yangtze Delta, separate dummy variables for the intersection with the past and contemporaneous course of the Yellow river, access to a river, and access to a lake. Regressions in all columns with macroregion and $2 \times 2$ degree grid-cell fixed effects. 'Kleibergen-Paap' represents the first-stage KleibergenPaap F-statistic for the excluded instrument. 


\section{Defining Cells as Intersected by Canal if they lie within a $11 \mathrm{~km}$ buffer of the Canal}

Table B.6: Sui Canal and Population Concentration in Historical Era: Robustness Canal defined as $11 \mathrm{~km}$ buffer.

\begin{tabular}{|c|c|c|c|c|c|c|c|c|}
\hline \multirow[t]{3}{*}{ Dependent Variable } & \multicolumn{8}{|c|}{ Total Population $(\mathrm{SD})_{t}$} \\
\hline & \multicolumn{4}{|c|}{ OLS } & \multicolumn{4}{|c|}{ 2SLS-IV } \\
\hline & (1) & $(2)$ & $(3)$ & $(4)$ & (5) & $(6)$ & (7) & (8) \\
\hline \multirow[t]{2}{*}{ Sui Canal } & $\begin{array}{c}0.074 \\
(0.213)\end{array}$ & $\begin{array}{c}0.007 \\
(0.146)\end{array}$ & $\begin{array}{c}0.717^{* *} \\
(0.302)\end{array}$ & $\begin{array}{c}0.956^{* * *} \\
(0.309)\end{array}$ & $\begin{array}{l}-0.005 \\
(0.416)\end{array}$ & $\begin{array}{l}-0.239 \\
(0.232)\end{array}$ & $\begin{array}{c}0.699 * * * \\
(0.260)\end{array}$ & $\begin{array}{c}0.666^{* * *} \\
(0.198)\end{array}$ \\
\hline & & & & & \multicolumn{4}{|c|}{ First Stage Regression: Sui Canal } \\
\hline Straight line & & & & & $\begin{array}{c}0.570^{* * *} \\
(0.160)\end{array}$ & $\begin{array}{c}0.574^{* * *} \\
(0.162)\end{array}$ & $\begin{array}{c}0.574^{* * *} \\
(0.162)\end{array}$ & $\begin{array}{c}0.576^{* * *} \\
(0.163)\end{array}$ \\
\hline Year of Census (LHS) & 2 & 140 & 742 & 1102 & 2 & 140 & 742 & 1102 \\
\hline Climate Controls & yes & yes & yes & yes & yes & yes & yes & yes \\
\hline Geography Controls & yes & yes & yes & yes & yes & yes & yes & yes \\
\hline $2 \times 2$ degree $\mathrm{FE}$ & yes & yes & yes & yes & yes & yes & yes & yes \\
\hline Kleibergen-Paap F-statistic & & & & & 12.75 & 12.59 & 12.59 & 12.50 \\
\hline Obs. & 1,281 & 1,281 & 1,281 & 1,281 & 1,281 & 1,281 & 1,281 & 1,281 \\
\hline
\end{tabular}

Notes: ${ }^{*} p<0.10,{ }^{* *} p<0.05,{ }^{* * *} p<0.01$. Standard errors clustered at $2 \times 2$ degree grid cells reported in parentheses. 'Year of Census (LHS)' indicates the census to which the LHS variable corresponds. Climate controls include (log) precipitation and $(\log )$ temperature. Geography controls include latitude, (log) distance to coast, (log) elevation, (log) ruggedness, (log) area of grid cell, $(\log )$ agricultural suitability, and $(\log )$ rice suitability. Furthermore, the following geography-related dummy variables are included: Coastline intersection, Yangtze River, Yangtze Delta, separate dummy variables for the intersection with the past and contemporaneous course of the Yellow river, access to a river, and access to a lake. Regressions in all columns with macroregion and $2 \times 2$ degree grid-cell fixed effects. 'Kleibergen-Paap' represents the first-stage KleibergenPaap F-statistic for the excluded instrument. 


\section{Omit 2×2 Grid Cell Fixed Effects}

Table B.7: Sui Canal and Population Concentration in Historical Era: Omit $2 \times 2$ Grid Cell Fixed Effects.

\begin{tabular}{|c|c|c|c|c|c|c|c|c|}
\hline \multirow[t]{3}{*}{ Dependent Variable } & \multicolumn{8}{|c|}{ Total Population $(\mathrm{SD})_{t}$} \\
\hline & \multicolumn{4}{|c|}{ OLS } & \multicolumn{4}{|c|}{ 2SLS-IV } \\
\hline & (1) & $(2)$ & $(3)$ & $(4)$ & (5) & (6) & (7) & (8) \\
\hline \multirow[t]{2}{*}{ Sui Canal } & $\begin{array}{c}0.043 \\
(0.135)\end{array}$ & $\begin{array}{c}0.034 \\
(0.139)\end{array}$ & $\begin{array}{c}0.908^{* *} \\
(0.357)\end{array}$ & $\begin{array}{c}0.980^{* *} \\
(0.382)\end{array}$ & $\begin{array}{c}0.110 \\
(0.302)\end{array}$ & $\begin{array}{c}-0.091 \\
(0.229)\end{array}$ & $\begin{array}{c}0.819^{* *} \\
(0.395)\end{array}$ & $\begin{array}{l}0.799^{* *} \\
(0.336)\end{array}$ \\
\hline & & & & & \multicolumn{4}{|c|}{ First Stage Regression: Sui Canal } \\
\hline Straight line & & & & & $\begin{array}{c}0.611^{* * *} \\
(0.165)\end{array}$ & $\begin{array}{c}0.607^{* * *} \\
(0.166)\end{array}$ & $\begin{array}{c}0.607^{* * *} \\
(0.166)\end{array}$ & $\begin{array}{c}0.612^{* * *} \\
(0.168)\end{array}$ \\
\hline Year of Census (LHS) & 2 & 140 & 742 & 1102 & 2 & 140 & 742 & 1102 \\
\hline Climate Controls & yes & yes & yes & yes & yes & yes & yes & yes \\
\hline Geography Controls & yes & yes & yes & yes & yes & yes & yes & yes \\
\hline $2 \times 2$ degree $\mathrm{FE}$ & no & no & no & no & no & no & no & no \\
\hline Kleibergen-Paap F-statistic & & & & & 13.70 & 13.29 & 13.29 & 13.19 \\
\hline Obs. & 1,281 & 1,281 & 1,281 & 1,281 & 1,281 & 1,281 & 1,281 & 1,281 \\
\hline
\end{tabular}

Notes: ${ }^{*} p<0.10,{ }^{* *} p<0.05,{ }^{* * *} p<0.01$. Standard errors clustered at $2 \times 2$ degree grid cells reported in parentheses. 'Year of Census (LHS)' indicates the census to which the LHS variable corresponds. Climate controls include (log) precipitation and $(\log )$ temperature. Geography controls include latitude, (log) distance to coast, (log) elevation, (log) ruggedness, (log) area of grid cell, (log) agricultural suitability, and (log) rice suitability. Furthermore, the following geography-related dummy variables are included: Coastline intersection, Yangtze River, Yangtze Delta, separate dummy variables for the intersection with the past and contemporaneous course of the Yellow river, access to a river, and access to a lake. Regressions in all columns with macroregion and $2 \times 2$ degree grid-cell fixed effects. 'Kleibergen-Paap' represents the first-stage KleibergenPaap F-statistic for the excluded instrument. 


\section{Alternative Clustering Approaches}

Table B.8: Sui Canal and Population Concentration in Historical Era:: Clustering

\begin{tabular}{|c|c|c|c|c|c|c|c|c|}
\hline \multirow[t]{3}{*}{ Dependent Variable } & \multicolumn{8}{|c|}{ Total Population $(\mathrm{SD})_{t}$} \\
\hline & \multicolumn{4}{|c|}{ OLS } & \multicolumn{4}{|c|}{ 2SLS-IV } \\
\hline & (1) & $(2)$ & $(3)$ & $(4)$ & $(5)$ & $(6)$ & $(7)$ & $(8)$ \\
\hline \multirow[t]{2}{*}{ Sui Canal } & $\begin{array}{l}-0.021 \\
(0.153)\end{array}$ & $\begin{array}{c}-0.031 \\
(0.153)\end{array}$ & $\begin{array}{c}0.789^{* *} \\
(0.249)\end{array}$ & $\begin{array}{c}0.925^{* *} \\
(0.346)\end{array}$ & $\begin{array}{l}-0.005 \\
(0.352)\end{array}$ & $\begin{array}{l}-0.228 \\
(0.325)\end{array}$ & $\begin{array}{c}0.668^{* * *} \\
(0.164)\end{array}$ & $\begin{array}{c}0.634^{*} \\
(0.368)\end{array}$ \\
\hline & & & & & \multicolumn{4}{|c|}{ First Stage Regression: Sui Canal } \\
\hline Straight line & & & & & $\begin{array}{c}0.597^{* * *} \\
(0.166)\end{array}$ & $\begin{array}{c}0.601^{* * *} \\
(0.169)\end{array}$ & $\begin{array}{c}0.601^{* * *} \\
(0.169)\end{array}$ & $\begin{array}{c}0.606^{* * *} \\
(0.171)\end{array}$ \\
\hline Year of Census (LHS) & 2 & 140 & 742 & 1102 & 2 & 140 & 742 & 1102 \\
\hline Climate Controls & yes & yes & yes & yes & yes & yes & yes & yes \\
\hline Geography Controls & yes & yes & yes & yes & yes & yes & yes & yes \\
\hline $2 \times 2$ degree $\mathrm{FE}$ & yes & yes & yes & yes & yes & yes & yes & yes \\
\hline Kleibergen-Paap F-statistic & & & & & 12.93 & 12.68 & 12.68 & 12.59 \\
\hline Obs. & 1,281 & 1,281 & 1,281 & 1,281 & 1,281 & 1,281 & 1,281 & 1,281 \\
\hline
\end{tabular}

Notes: ${ }^{*} p<0.10,{ }^{*} p<0.05,{ }^{* * *} p<0.01$. Standard errors computed using the approach of Conley $(1999)$ reported in parentheses (cut-off 2 degrees). 'Year of Census (LHS)' indicates the census to which the LHS variable corresponds. Climate controls include (log) precipitation and (log) temperature. Geography controls include latitude, (log) distance to coast, (log) elevation, ( $\log$ ) ruggedness, (log) area of grid cell, (log) agricultural suitability, and (log) rice suitability. Furthermore, the following geography-related dummy variables are included: Coastline intersection, Yangtze River, Yangtze Delta, separate dummy variables for the intersection with the past and contemporaneous course of the Yellow river, access to a river, and access to a lake. Regressions in all columns with macroregion and $2 \times 2$ degree grid-cell fixed effects. 'Kleibergen-Paap' represents the first-stage Kleibergen-Paap F-statistic for the excluded instrument. 


\section{Falsification: Shifting Sui Canal}

Table B.9: Sui Canal and Population Concentration in Historical Era: Shift Canal

\begin{tabular}{|c|c|c|c|c|c|c|c|c|}
\hline \multirow[t]{3}{*}{ Dependent Variable } & \multicolumn{8}{|c|}{ Total Population $(\mathrm{SD})_{t}$} \\
\hline & \multicolumn{4}{|c|}{ 100km Inward Shift } & \multicolumn{4}{|c|}{ 100km Outward Shift } \\
\hline & (1) & $(2)$ & (3) & (4) & $(5)$ & (6) & (7) & (8) \\
\hline Sui Canal & $\begin{array}{c}-0.230 \\
(0.186)\end{array}$ & $\begin{array}{l}-0.149 \\
(0.141)\end{array}$ & $\begin{array}{c}0.032 \\
(0.225)\end{array}$ & $\begin{array}{c}-0.223 \\
(0.191)\end{array}$ & $\begin{array}{c}0.060 \\
(0.254)\end{array}$ & $\begin{array}{c}0.232 \\
(0.153)\end{array}$ & $\begin{array}{c}0.183 \\
(0.258)\end{array}$ & $\begin{array}{c}0.061 \\
(0.147)\end{array}$ \\
\hline Year of Census (LHS) & 2 & 140 & 742 & 1102 & 2 & 140 & 742 & 1102 \\
\hline Climate Controls & yes & yes & yes & yes & yes & yes & yes & yes \\
\hline Geography Controls & yes & yes & yes & yes & yes & yes & yes & yes \\
\hline $2 \times 2$ degree $\mathrm{FE}$ & yes & yes & yes & yes & yes & yes & yes & yes \\
\hline Obs. & 1,281 & 1,281 & 1,281 & 1,281 & 1,281 & 1,281 & 1,281 & 1,281 \\
\hline
\end{tabular}

Notes: ${ }^{*} p<0.10,{ }^{* *} p<0.05,{ }^{* * *} p<0.01$. Standard errors clustered at $2 \times 2$ degree grid cells reported in parentheses. 'Year of Census (LHS)' indicates the census to which the LHS variable corresponds. Climate controls include (log) precipitation and (log) temperature. Geography controls include latitude, (log) distance to coast, (log) elevation, (log) ruggedness, (log) area of grid cell, (log) agricultural suitability, and (log) rice suitability. Furthermore, the following geography-related dummy variables are included: Coastline intersection, Yangtze River, Yangtze Delta, separate dummy variables for the intersection with the past and contemporaneous course of the Yellow river, access to a river, and access to a lake. Regressions in all columns with macroregion and $2 \times 2$ degree grid-cell fixed effects. 


\title{
C Robustness and Falsification Checks Current Era
}

\author{
Restricting Sample to Grid Cells Within 75 Kilometers of Sui Canal
}

Table C.1: Sui Canal and Population Concentration and Economic Activity 2010: Cells within 75 kilometers of Sui Canal

\begin{tabular}{|c|c|c|c|c|c|c|}
\hline & \multicolumn{3}{|c|}{ OLS } & \multicolumn{3}{|c|}{ 2SLS-IV } \\
\hline & $\begin{array}{c}\text { Population (SD) } \\
\text { (1) }\end{array}$ & $\begin{array}{c}\text { GDP (SD) } \\
(2)\end{array}$ & $\begin{array}{c}\text { GDP per } \\
\text { capita }(\mathrm{SD}) \\
(3)\end{array}$ & $\begin{array}{c}\text { Population (SD) } \\
\text { (4) }\end{array}$ & $\begin{array}{c}\text { GDP (SD) } \\
(5)\end{array}$ & $\begin{array}{c}\text { GDP per } \\
\text { capita }(\mathrm{SD}) \\
(6)\end{array}$ \\
\hline \multirow[t]{2}{*}{$\begin{array}{l}\text { Sui Canal } \\
\text { Destroyed Section }\end{array}$} & $\begin{array}{c}0.334^{*} \\
(0.182)\end{array}$ & $\begin{array}{c}0.010 \\
(0.090)\end{array}$ & $\begin{array}{c}-0.163^{* *} \\
(0.066)\end{array}$ & $\begin{array}{c}0.682^{* *} \\
(0.278)\end{array}$ & $\begin{array}{c}0.097 \\
(0.123)\end{array}$ & $\begin{array}{c}-0.221^{* * *} \\
(0.045)\end{array}$ \\
\hline & & & & \multicolumn{3}{|c|}{ First Stage Regression } \\
\hline $\begin{array}{l}\text { Straight line } \\
\text { Destroyed Section }\end{array}$ & & & & $\begin{array}{c}0.858^{* * *} \\
(0.087)\end{array}$ & $\begin{array}{c}0.858^{* * *} \\
(0.087)\end{array}$ & $\begin{array}{c}0.858^{* * *} \\
(0.087)\end{array}$ \\
\hline Climate Controls & yes & yes & yes & yes & yes & yes \\
\hline Geography Controls & yes & yes & yes & yes & yes & yes \\
\hline $2 \times 2$ degree $\mathrm{FE}$ & yes & yes & yes & yes & yes & yes \\
\hline Kleibergen-Paap & & & & 97.27 & 97.27 & 97.27 \\
\hline Obs. & 235 & 235 & 235 & 235 & 235 & 235 \\
\hline
\end{tabular}

Notes: ${ }^{*} p<0.10,{ }^{* *} p<0.05,{ }^{* * *} p<0.01$. Standard errors clustered at $2 \times 2$ degree grid cells reported in parentheses. Climate controls include (log) precipitation and $(\log )$ temperature. Geography controls include latitude, (log) distance to coast, $(\log )$ elevation, $(\log )$ ruggedness, $(\log )$ area of grid cell, ( $\log )$ agricultural suitability, and (log) rice suitability. Furthermore, the following geography-related dummy variables are included: Coastline intersection, Yangtze River, Yangtze Delta, separate dummy variables for the intersection with the past and contemporaneous course of the Yellow river, access to a river, and access to a lake. Regressions in all columns with macroregion and $2 \times 2$ degree grid-cell fixed effects. 'KleibergenPaap' represents the first-stage Kleibergen-Paap F-statistic for the excluded instrument. 


\section{Adding Fourth-Order Longitude/Latitude Polynomial}

Table C.2: Sui Canal and Population Concentration and Economic Activity 2010: Longitude/Latitude Polynomial

\begin{tabular}{|c|c|c|c|c|c|c|}
\hline & \multicolumn{3}{|c|}{ OLS } & \multicolumn{3}{|c|}{ 2SLS-IV } \\
\hline & $\begin{array}{c}\text { Population (SD) } \\
\text { (1) }\end{array}$ & $\begin{array}{c}\text { GDP (SD) } \\
(2)\end{array}$ & $\begin{array}{c}\text { GDP per } \\
\text { capita }(\mathrm{SD}) \\
(3)\end{array}$ & $\begin{array}{c}\text { Population (SD) } \\
\text { (4) }\end{array}$ & $\begin{array}{c}\text { GDP (SD) } \\
(5)\end{array}$ & $\begin{array}{c}\text { GDP per } \\
\text { capita }(\mathrm{SD}) \\
(6)\end{array}$ \\
\hline \multirow[t]{2}{*}{$\begin{array}{l}\text { Sui Canal } \\
\text { Destroyed Section }\end{array}$} & $\begin{array}{c}0.226^{* * *} \\
(0.058)\end{array}$ & $\begin{array}{l}-0.038 \\
(0.102)\end{array}$ & $\begin{array}{l}-0.061 \\
(0.058)\end{array}$ & $\begin{array}{c}0.433^{* * *} \\
(0.111)\end{array}$ & $\begin{array}{l}-0.028 \\
(0.155)\end{array}$ & $\begin{array}{l}-0.130^{*} \\
(0.075)\end{array}$ \\
\hline & & & & \multicolumn{3}{|c|}{ First Stage Regression } \\
\hline $\begin{array}{l}\text { Straight line } \\
\text { Destroyed Section }\end{array}$ & & & & $\begin{array}{c}0.898^{* * * *} \\
(0.082)\end{array}$ & $\begin{array}{c}0.898^{* * *} \\
(0.082)\end{array}$ & $\begin{array}{c}0.898^{* * *} \\
(0.082)\end{array}$ \\
\hline 4th order lon/lat polynomial & yes & yes & yes & yes & yes & yes \\
\hline Climate Controls & yes & yes & yes & yes & yes & yes \\
\hline Geography Controls & yes & yes & yes & yes & yes & yes \\
\hline $2 \times 2$ degree $\mathrm{FE}$ & yes & yes & yes & yes & yes & yes \\
\hline Kleibergen-Paap & & & & 119.2 & 119.2 & 119.2 \\
\hline Obs. & 1,254 & 1,254 & 1,254 & 1,254 & 1,254 & 1,254 \\
\hline
\end{tabular}

Notes: ${ }^{*} p<0.10,{ }^{* *} p<0.05,{ }^{* *} p<0.01$. Standard errors clustered at $2 \times 2$ degree grid cells reported in parentheses.

Climate controls include (log) precipitation and (log) temperature. Geography controls include latitude, (log) distance to coast, $(\log )$ elevation, $(\log )$ ruggedness, $(\log )$ area of grid cell, $(\log )$ agricultural suitability, and (log) rice suitability. Furthermore, the following geography-related dummy variables are included: Coastline intersection, Yangtze River, Yangtze Delta, separate dummy variables for the intersection with the past and contemporaneous course of the Yellow river, access to a river, and access to a lake. Regressions in all columns with macroregion and $2 \times 2$ degree grid-cell fixed effects. 'KleibergenPaap' represents the first-stage Kleibergen-Paap F-statistic for the excluded instrument. 


\section{Defining Cells as Intersected by Canal if they lie within a $11 \mathrm{~km}$ buffer of the Canal}

Table C.3: Sui Canal and Population Concentration and Economic Activity 2010: Robustness Canal defined as $11 \mathrm{~km}$ buffer.

\begin{tabular}{|c|c|c|c|c|c|c|}
\hline & \multicolumn{3}{|c|}{ OLS } & \multicolumn{3}{|c|}{ 2SLS-IV } \\
\hline & $\begin{array}{c}\text { Population (SD) } \\
\text { (1) }\end{array}$ & $\begin{array}{c}\text { GDP (SD) } \\
(2)\end{array}$ & $\begin{array}{c}\text { GDP per } \\
\text { capita }(\mathrm{SD}) \\
(3)\end{array}$ & $\begin{array}{c}\text { Population (SD) } \\
(4)\end{array}$ & $\begin{array}{c}\text { GDP (SD) } \\
(5)\end{array}$ & $\begin{array}{c}\text { GDP per } \\
\text { capita (SD) } \\
(6)\end{array}$ \\
\hline \multirow[t]{2}{*}{$\begin{array}{l}\text { Sui Canal } \\
\text { Destroyed Section }\end{array}$} & $\begin{array}{c}0.267^{* *} \\
(0.100)\end{array}$ & $\begin{array}{l}-0.036 \\
(0.104)\end{array}$ & $\begin{array}{c}-0.179^{* * *} \\
(0.064)\end{array}$ & $\begin{array}{c}0.530^{* * *} \\
(0.139)\end{array}$ & $\begin{array}{l}0.005 \\
(0.191)\end{array}$ & $\begin{array}{l}-0.158^{* *} \\
(0.071)\end{array}$ \\
\hline & & & & \multicolumn{3}{|c|}{ First Stage Regression: Sui Canal Destroyed Section } \\
\hline $\begin{array}{l}\text { Straight line } \\
\text { Destroyed Section }\end{array}$ & & & & $\begin{array}{c}0.823^{* * *} \\
(0.077)\end{array}$ & $\begin{array}{c}0.823^{* * *} \\
(0.077)\end{array}$ & $\begin{array}{c}0.823^{* * *} \\
(0.077)\end{array}$ \\
\hline Climate Controls & yes & yes & yes & yes & yes & yes \\
\hline Geography Controls & yes & yes & yes & yes & yes & yes \\
\hline $2 \times 2$ degree $\mathrm{FE}$ & yes & yes & yes & yes & yes & yes \\
\hline Kleibergen-Paap & & & & 113.3 & 113.3 & 113.3 \\
\hline Obs. & 1,254 & 1,254 & 1,254 & 1,254 & 1,254 & 1,254 \\
\hline
\end{tabular}

Notes: ${ }^{*} p<0.10,{ }^{* *} p<0.05,{ }^{* * *} p<0.01$. Standard errors clustered at $2 \times 2$ degree grid cells reported in parentheses. Climate controls include (log) precipitation and (log) temperature. Geography controls include latitude, (log) distance to coast, ( $\log$ ) elevation, ( $\log )$ ruggedness, $(\log )$ area of grid cell, (log) agricultural suitability, and (log) rice suitability. Furthermore, the following geography-related dummy variables are included: Coastline intersection, Yangtze River, Yangtze Delta, separate dummy variables for the intersection with the past and contemporaneous course of the Yellow river, access to a river, and access to a lake. Regressions in all columns with macroregion and $2 \times 2$ degree grid-cell fixed effects. 'KleibergenPaap' represents the first-stage Kleibergen-Paap F-statistic for the excluded instrument. 


\section{Omit $2 \times 2$ Grid Cell Fixed Effects}

Table C.4: Sui Canal and Population Concentration and Economic Activity 2010: Omit $2 \times 2$ Grid Cell Fixed Effects.

\begin{tabular}{|c|c|c|c|c|c|c|}
\hline & \multicolumn{3}{|c|}{ OLS } & \multicolumn{3}{|c|}{ 2SLS-IV } \\
\hline & $\begin{array}{c}\text { Population (SD) } \\
\text { (1) }\end{array}$ & $\begin{array}{c}\text { GDP }(\mathrm{SD}) \\
(2)\end{array}$ & $\begin{array}{c}\text { GDP per } \\
\text { capita }(\mathrm{SD}) \\
(3)\end{array}$ & $\begin{array}{c}\text { Population (SD) } \\
\text { (4) }\end{array}$ & $\begin{array}{c}\text { GDP (SD) } \\
(5) \\
\end{array}$ & $\begin{array}{c}\text { GDP per } \\
\text { capita }(\mathrm{SD}) \\
(6)\end{array}$ \\
\hline \multirow[t]{2}{*}{$\begin{array}{l}\text { Sui Canal } \\
\text { Destroyed Section }\end{array}$} & $\begin{array}{c}0.384^{* * *} \\
(0.062)\end{array}$ & $\begin{array}{l}0.139^{*} \\
(0.077)\end{array}$ & $\begin{array}{l}-0.059 \\
(0.057)\end{array}$ & $\begin{array}{c}0.558^{* * *} \\
(0.114)\end{array}$ & $\begin{array}{c}0.141 \\
(0.121)\end{array}$ & $\begin{array}{c}-0.158^{* * *} \\
(0.056)\end{array}$ \\
\hline & & & & \multicolumn{3}{|c|}{ First Stage Regression: Sui Canal Destroyed Section } \\
\hline $\begin{array}{l}\text { Straight line } \\
\text { Destroyed Section }\end{array}$ & & & & $\begin{array}{c}0.925^{* * *} \\
(0.074)\end{array}$ & $\begin{array}{c}0.925^{* * *} \\
(0.074)\end{array}$ & $\begin{array}{c}0.925^{* * *} \\
(0.074)\end{array}$ \\
\hline Climate Controls & yes & yes & yes & yes & yes & yes \\
\hline Geography Controls & yes & yes & yes & yes & yes & yes \\
\hline $2 \times 2$ degree $\mathrm{FE}$ & no & no & no & no & no & no \\
\hline Kleibergen-Paap & & & & 155.9 & 155.9 & 155.9 \\
\hline Obs. & 1,254 & 1,254 & 1,254 & 1,254 & 1,254 & 1,254 \\
\hline
\end{tabular}

Notes: ${ }^{*} p<0.10,{ }^{* *} p<0.05,{ }^{* * *} p<0.01$. Standard errors clustered at $2 \times 2$ degree grid cells reported in parentheses. Climate controls include (log) precipitation and (log) temperature. Geography controls include latitude, (log) distance to coast, ( $\log$ ) elevation, ( $\log )$ ruggedness, ( $\log$ ) area of grid cell, ( $\log$ ) agricultural suitability, and (log) rice suitability. Furthermore, the following geography-related dummy variables are included: Coastline intersection, Yangtze River, Yangtze Delta, separate dummy variables for the intersection with the past and contemporaneous course of the Yellow river, access to a river, and access to a lake. Regressions in all columns with macroregion and $2 \times 2$ degree grid-cell fixed effects. 'KleibergenPaap' represents the first-stage Kleibergen-Paap F-statistic for the excluded instrument. 


\section{Alternative Clustering Approaches}

Table C.5: Sui Canal and Population Concentration and Economic Activity 2010: Clustering

\begin{tabular}{|c|c|c|c|c|c|c|}
\hline & \multicolumn{3}{|c|}{ OLS } & \multicolumn{3}{|c|}{ 2SLS-IV } \\
\hline & $\begin{array}{c}\text { Population (SD) } \\
(1)\end{array}$ & $\begin{array}{c}\text { GDP (SD) } \\
(2)\end{array}$ & $\begin{array}{c}\text { GDP per } \\
\text { capita }(\mathrm{SD}) \\
(3)\end{array}$ & $\begin{array}{c}\text { Population (SD) } \\
(4)\end{array}$ & $\begin{array}{c}\text { GDP (SD) } \\
(5)\end{array}$ & $\begin{array}{c}\text { GDP per } \\
\text { capita }(\mathrm{SD}) \\
(6)\end{array}$ \\
\hline \multirow[t]{2}{*}{$\begin{array}{l}\text { Sui Canal } \\
\text { Destroyed Section }\end{array}$} & $\begin{array}{c}0.269^{* *} \\
(0.116)\end{array}$ & $\begin{array}{l}-0.014 \\
(0.148)\end{array}$ & $\begin{array}{l}-0.076 \\
(0.072)\end{array}$ & $\begin{array}{c}0.484^{* * *} \\
(0.150)\end{array}$ & $\begin{array}{c}0.004 \\
(0.103)\end{array}$ & $\begin{array}{l}-0.144^{*} \\
(0.086)\end{array}$ \\
\hline & & & & \multicolumn{3}{|c|}{ First Stage Regression } \\
\hline $\begin{array}{l}\text { Straight line } \\
\text { Destroyed Section }\end{array}$ & & & & $\begin{array}{c}0.900^{* * *} \\
(0.081)\end{array}$ & $\begin{array}{c}0.900^{* * *} \\
(0.081)\end{array}$ & $\begin{array}{c}0.900^{* * *} \\
(0.081)\end{array}$ \\
\hline Climate Controls & yes & yes & yes & yes & yes & yes \\
\hline Geography Controls & yes & yes & yes & yes & yes & yes \\
\hline $2 \times 2$ degree $\mathrm{FE}$ & yes & yes & yes & yes & yes & yes \\
\hline Kleibergen-Paap & & & & 124.2 & 124.2 & 124.2 \\
\hline Obs. & 1,254 & 1,254 & 1,254 & 1,254 & 1,254 & 1,254 \\
\hline
\end{tabular}

Notes: ${ }^{*} p<0.10,{ }^{*} p<0.05,{ }^{* *} p<0.01$. Standard errors computed using the approach of Conley (1999) reported in parentheses (cut-off 2 degrees). Climate controls include (log) precipitation and (log) temperature. Geography controls include latitude, $(\log )$ distance to coast, $(\log )$ elevation, $(\log )$ ruggedness, $(\log )$ area of grid cell, $(\log )$ agricultural suitability, and $(\log )$ rice suitability. Furthermore, the following geography-related dummy variables are included: Coastline intersection, Yangtze River, Yangtze Delta, separate dummy variables for the intersection with the past and contemporaneous course of the Yellow river, access to a river, and access to a lake. Regressions in all columns with macroregion and $2 \times 2$ degree grid-cell fixed effects. 'Kleibergen-Paap' represents the first-stage Kleibergen-Paap F-statistic for the excluded instrument. 


\section{Gauging Influence of Omitted Variables}

Table C.6: Oster (Forthcoming $)$ Approach to Gauge Influence of Omitted Variables

\begin{tabular}{lcccc}
\hline Dependent Variable & $\delta$ & $R^{2}$ & $R^{2}$ & $R_{\text {max }}^{2}$ \\
& & $2 \times 2 \mathrm{FE}$ & full set of controls & \\
\hline Population 2010 (SD) & -10.595 & 0.212 & 0.453 & 0.589 \\
GDP 2010 (SD) & 0.629 & 0.266 & 0.447 & 0.582 \\
GDP per capita 2010 (SD) & 6.307 & 0.147 & 0.304 & 0.395 \\
\hline
\end{tabular}

Notes: The parameter $\delta$ represents how strong the influence of unobservables relative to observables would have to be in order to suppress the Sui Canal effect. $2 \times 2 \mathrm{FE}$ captures the explanatory power obtained from regressions in which we only control for $2 \times 2$ grid cell fixed effects. $R^{2}$ full set of controls reflects the explanatory power obtained from the regressions that control for full set of controls. Following the recommendation of Oster (Forthcoming), we assume that the maximum achievable R-squared exceeds the R-squared obtained when including all observable covariates by $30 \%$. Negative values of $\delta$ indicate that the estimates are, if anything, biased downwards. 


\section{Night-Time Light Intensity}

Table C.7: Sui Canal and Population Concentration and Economic Activity 2010: Night-Time Light Intensity

\begin{tabular}{lcc}
\hline Dependent Variable & \multicolumn{2}{c}{ Log Night-Time Light Intensity (SD) } \\
\cline { 2 - 3 } & OLS & 2SLS-IV \\
\cline { 2 - 3 } & $(1)$ & $(2)$ \\
\hline Sui Canal & $0.111^{* *}$ & $0.164^{* * *}$ \\
Destroyed Section & $(0.055)$ & $(0.031)$ \\
& & First Stage Regression: Sui Canal Destroyed Section \\
\cline { 3 - 3 } & & $0.900^{* * *}$ \\
Straight line & & $(0.081)$ \\
Destroyed Section & & yes \\
Climate Controls & yes & yes \\
Geography Controls & yes & yes \\
$2 \times 2$ degree FE & yes & 124.2 \\
Kleibergen-Paap & & 1,254 \\
Obs. & 1,254 &
\end{tabular}

Notes: $* p<0.10,{ }^{* *} p<0.05,{ }^{* *} p<0.01$. Standard errors clustered at $2 \times 2$ degree grid cells reported in parentheses. Climate controls include (log) precipitation and (log) temperature. Geography controls include latitude, (log) distance to coast, ( $\log )$ elevation, ( $\log )$ ruggedness, ( $\log )$ area of grid cell, ( $\log$ ) agricultural suitability, and (log) rice suitability. Furthermore, the following geography-related dummy variables are included: Coastline intersection, Yangtze River, Yangtze Delta, separate dummy variables for the intersection with the past and contemporaneous course of the Yellow river, access to a river, and access to a lake. Regressions in all columns with macroregion and $2 \times 2$ degree grid-cell fixed effects. 'KleibergenPaap' represents the first-stage Kleibergen-Paap F-statistic for the excluded instrument. 


\section{Falsification: Shifting Sui Canal}

Table C.8: Sui Canal and Population Concentration and Economic Activity 2010: Shifting Canal

\begin{tabular}{|c|c|c|c|c|c|c|}
\hline & \multicolumn{3}{|c|}{ 100km Inward Shift } & \multicolumn{3}{|c|}{ 100km Outward Shift } \\
\hline & $\begin{array}{c}\text { Population (SD) } \\
(1) \\
\end{array}$ & $\begin{array}{c}\text { GDP (SD) } \\
(2)\end{array}$ & $\begin{array}{c}\text { GDP per } \\
\text { capita }(\mathrm{SD}) \\
(3)\end{array}$ & $\begin{array}{c}\text { Population (SD) } \\
(4) \\
\end{array}$ & $\begin{array}{c}\text { GDP (SD) } \\
(5)\end{array}$ & $\begin{array}{c}\text { GDP per } \\
\text { capita }(\mathrm{SD}) \\
(6)\end{array}$ \\
\hline $\begin{array}{l}\text { Sui Canal } \\
\text { Destroyed Section }\end{array}$ & $\begin{array}{c}0.196 \\
(0.139)\end{array}$ & $\begin{array}{l}-0.023 \\
(0.162)\end{array}$ & $\begin{array}{l}-0.085 \\
(0.116)\end{array}$ & $\begin{array}{l}-0.018 \\
(0.150)\end{array}$ & $\begin{array}{l}0.195^{*} \\
(0.099)\end{array}$ & $\begin{array}{c}0.061 \\
(0.110)\end{array}$ \\
\hline Climate Controls & yes & yes & yes & yes & yes & yes \\
\hline Geography Controls & yes & yes & yes & yes & yes & yes \\
\hline $2 \times 2$ degree $\mathrm{FE}$ & yes & yes & yes & yes & yes & yes \\
\hline Obs. & 1,254 & 1,254 & 1,254 & 1,254 & 1,254 & 1,254 \\
\hline
\end{tabular}

Notes: ${ }^{*} p<0.10,{ }^{* *} p<0.05,{ }^{* * *} p<0.01$. Standard errors clustered at $2 \times 2$ degree grid cells reported in parentheses. Climate controls include (log) precipitation and $(\log )$ temperature. Geography controls include latitude, (log) distance to coast, (log) elevation, (log) ruggedness, (log) area of grid cell, (log) agricultural suitability, and (log) rice suitability. Furthermore, the following geography-related dummy variables are included: Coastline intersection, Yangtze River, Yangtze Delta, separate dummy variables for the intersection with the past and contemporaneous course of the Yellow river, access to a river, and access to a lake. Regressions in all columns with macroregion and $2 \times 2$ degree grid-cell fixed effects. 